\title{
Some conceptual difficulties in the theory of social conflict $^{1}$
}

\author{
CLINTON F. FINK
}

Center for Research on Conflict Resolution, University of Michigan

\section{THE CASE FOR A GENERALIST APPROACH TO THE STUDY OF CONFLICT}

The quest for scientific knowledge about social conflict has a long and complex history, closely interwoven with the entire history of social science. In many disciplines and from many viewpoints, great bodies of data have been collected, and countless generalizations, hypotheses, and theories have been constructed to account for social conflict phenomena. During the past dozen years, the problem of integrating this knowledge has received considerable attention, especially in the pages of new multidisciplinary journals (Journal of Conflict Resolution, 1957-; Journal of Peace Research, 1964-), multidisciplinary symposia (International Sociological Association, 1957;

${ }^{1}$ This study is part of the author's research program on "Effects of Social Conflict," supported by research grants GS-697 and GS-1464 from the National Science Foundation. The present text contains the first two chapters of a projected longer work which will examine in detail the problems of classifying and describing social conflicts for scientific purposes, problems which must be solved by any general theory of conflict. For numerous stimulating discussions about these problems, and for helpful comments on earlier drafts, I am especially indebted to Jacques Bude, Elizabeth Converse, Lucille Doke, Ronald Edmonds, Mary Ellin Fink, $H$. Merrill Jackson, Martin Patchen, and Kendall O. Price.
Kahn and Boulding, 1964; McNeil, 1965; Ciba Foundation, 1966; Stagner, 1967), and numerous theoretical works by representatives of several disciplines. Since theory is the principal means of integrating scientific knowledge, the construction of a general theory of social conflict is considered by some writers to be a desirable step.

A typical argument in favor of general theory was offered in the first issue of the Journal of Conflict Resolution:

If intellectual progress is to be made in ... the study of international relations [it] must be made an interdisciplinary enterprise, drawing its discourse from all the social sciences, and even further. . . O Our belief in the fruitfulness of an interdisciplinary approach in this area is based on the conviction that the behavior and interactions of nations are not an isolated and self-contained area of empirical material, but part of a much wider field of behavior and interaction. . . . Conflict, which is perhaps the key concept in international relations, . . . is a phenomenon studied in many different fields: by sociologists, psychologists, psychiatrists, economists, and by political scientists. It occurs in many different situations: among members of a family, between labor and management, between political parties, and even within a single mind, as well as among nations. Many of the patterns and processes which characterize conflict in one area also characterize it in others. . . . It is not too much to claim that out of the contributions of many fields a general 
theory of conflict is emerging. The isolation of these various fields, however, has prevented the building of these contributions into an integrated whole. ... We welcome insights, theoretical models, and confirmatory tests from all spheres of conflict resolution; for we believe that only as all such areas are drawn on, can we devise an intellectual engine of sufficient power to move the greatest problem of our time - the prevention of war. This same engine will move us toward greater knowledge and greater power in all areas of conflict-in the personality, in the home, in industrial relations, and so on [Editorial, JCR, March 1957, pp. 1-2].

This passage contains two main arguments. The first is the argument for a multidisciplinary approach, based on the assumption that no existing social science discipline, by itself, contains sufficient intellectual resources to achieve an adequate theory of international conflict (nor, by implication, of any other kind of conflict). The second is the argument for a generalist approach, apparently based on the assumption that even if it is multidisciplinary, direct study of a given kind of conflict (e.g., international conflict) cannot, by itself, provide sufficient information on which to build an adequate theory covering that class of phenomena. The following discussion is concerned primarily with the generalist argument.

This argument says, in effect, that specialized concentration on a given type of conflict will lead to the neglect of certain facts or principles which are essential to an adequate understanding of that kind of conflict. This implies that a special theory (for example a theory of interpersonal, marital, intraorganizational, community, interethnic, class, or international conflict) will be inadequate to the extent that it is not informed by comparison with the other types or not imbedded in a more general theory of conflict. The scientific value of a general theory thus lies in its ability to provide greater understanding of each particular kind of conflict than can be provided by the relevant special theory, and consequently to provide a better account of the entire domain of conflict phenomena than could be provided by the total set of special theories.

\section{Objections to a General Theory}

SPECIALIST AND IDIOGRAPHIC ARGUMENTS

The generalist view is disputed by some writers, who question both the necessity and the desirability of treating several kinds of conflict as a single empirical domain, on grounds that crucial aspects of each particular kind of conflict are inevitably overlooked by theories of greater generality. For example, Hager et al. (1956) argue that the effort to understand religious conflicts in the same framework as ethnic and racial conflicts, as recommended by Williams (1947), had failed because of certain fundamental peculiarities of religion and religious groups. Similarly, Janowitz (1957) argues that the effort to subsume the phenomena of war under a general theory of conflict would probably fail, because several unique properties of nation-states and their military institutions require a detailed analysis not provided by general theories of conflict. Directly contradicting the generalist argument, these writers assert that a special theory for a given kind of conflict can provide greater understanding of the relevant phenomena than could be provided by a more general theory. These specialist arguments imply that true knowledge of war or of religious conflict consists in fully understanding the unique properties peculiar to each class of phenomena, rather than in subsuming them under more general principles.

If taken to the extreme, emphasis on the uniqueness of special cases becomes indis- 
tinguishable from an idiographic approach to knowledge, which holds that "true knowledge is of particulars” (K. Singer, 1949a). Aron (1957) comes close to this position when he argues that war is best studied by historical sociology, rather than by theoretical sociology, on grounds that each war is a unique configuration of diverse and not necessarily repeatable elements. Applied to other domains, such idiographic arguments would rule out not only general theories of conflict but also special theories of war, of religious conflict, or of any other class of conflict phenomena. Not only each war, but each instance of conflict would have to be analyzed in its own right from a historical or clinical viewpoint.

Granting the validity of an idiographic approach for certain purposes, its emphasis on the peculiarities of the single case is justifiable and self-consistent. However, once one admits the possibility of a special theory for one class of conflict phenomena, the entire discussion is shifted into a nomothetic framework, since even the most limited special theory aims to generalize about properties shared by all instances of a given type. In that framework, it becomes difficult to set arbitrary limits on how far one may fruitfully and validly generalize. If the uniqueness of the single case poses no inherent obstacle to a special theory which generalizes about a limited set of such cases, then why should the uniqueness of a single class of phenomena pose any greater obstacle to a more general theory covering several such classes? The idiographic and specialist objections express a belief that moving to higher levels of generality necessitates loss of information and thus less valid knowledge. In principle, such objections can be overcome by constructing theories which treat the unique properties of each case or of each subclass as specific values of theoretical variables, or as parameters defining the limits of special subtheories. If such a theory provides a satisfactory account of both the similarities and the differences among the phenomena in its empirical domain, then it can be judged adequate, no matter how general it happens to be.

\section{THE GRADUALIST ARGUMENT}

Idiographic objections to a general theory of conflict raise the issue of whether the kind of knowledge embodied in such a theory is desirable or even possible. A second kind of objection takes for granted the desirability and attainability of generalized knowledge about conflicts, but raises the issue of whether the immediate construction of a general theory is the best strategy for attaining it. For example, Dahrendorf (1958) argues that a general theory of conflict is a necessary component of a comprehensive theory of society, but that the sociological theory of conflict "would do well to confine itself for the time being to an explanation of the frictions between the rulers and the ruled in given social structural organizations," i.e., to building a theory of class conflict (p. 173). He bases this position on Merton's (1957, 1967) view that empirically testable "theories of the middle range" are the immediate task of sociological research, together with the assertion that a theory of class conflict is a middle range theory (Dahrendorf, 1959, p. x).

Merton's case for middle range theory is based on a broadly inductivist image of scientific progress, in which successively more general levels of theoretical integration are achieved gradually, each higher level theory representing a consolidation of several empirically well-grounded lower level theories. In this view, the ultimate goal of 
a complete theoretical integration of all sociological knowledge is attainable only in the distant future, so that current efforts to construct general systems of sociology are premature, unrealistic, and fruitless. Given the present state of knowledge, the development of middle range theories holds the largest promise for scientific advance, provided that the search for them is coupled with a pervasive concern to consolidate special theories into more general theories as soon as warranted (Merton, 1967, p. 52). Dahrendorf's "middle range" argument thus appears to be a "gradualist" objection to building a general theory of conflict now, on grounds that the existing accumulation of knowledge is only sufficient to permit fruitful theory construction at the level of special types such as class conflict.

This objection is deprived of some of its force, however, by the fact that the concept of "middle range theory" is somewhat ambiguous, and can be used equally well to justify a general theory of conflict. Merton himself suggests this possibility when, in order to illustrate one main characteristic of middle range theories (i.e., they are "sufficiently abstract to deal with differing spheres of social behavior and social structure, so that they transcend sheer description or empirical generalization"), he points to "the theory of social conflict [which] has been applied to ethnic and racial conflict, class conflict, and international conflict," as a typical example (Merton, 1967, p. 68). A second main characteristic of middle range theories is that they "cut across the distinction between micro-sociological problems . . . and macro-sociological problems." This would obviously apply to any theory of social conflict that included both smallscale conflicts, such as interpersonal quarrels, and large-scale conflicts, such as war, in its empirical domain. Furthermore, a theory of conflict is obviously not a general system of sociology. From this it is clear that a general theory of social conflict would be an example par excellence of a "middle range" theory.

But the adequacy of the gradualist argument does not depend on the definition of "middle range." Instead, it depends on the assessment of the current state of knowledge. Merton evidently believes, in agreement with the Conflict Resolution editorial cited above, that empirically well-grounded theories already exist for various special kinds of conflict, and that the time is ripe for efforts to integrate these theories into a more comprehensive general theory of social conflict. If this assessment is correct, then the gradualist objection would be met. However, no one has provided a direct demonstration that the currently available special theories of conflict actually warrant efforts at higher level theoretical integration. In fact, the proliferation of special theories in recent years suggests the opposite. Besides Dahrendorf's theory of class conflict, numerous other theories have appeared, covering such phenomena as community controversies (Coleman, 1957), international conflict (Koch et al., 1960; North et al., 1960), revolution (Davies, 1962; Johnson, 1966; Tanter and Midlarsky, 1967), war and revolution (Timasheff, 1965), or intraorganization conflict (Beals and Siegel, 1966; Goldman, 1966). But none of these theories has even been adequately tested, let alone accorded the status of a generally accepted account of the phenomena in its domain. And, in line with the gradualist approach, each theory is an effort to organize scattered findings or to improve upon previous theories covering the same class of phenomena. Though many of these writers are oriented toward the development of more general theories, 
they apparently believe, with Dahrendorf, that the existing level of knowledge demands integration at the level of their special theories, and does not yet warrant higher level integration.

However, the gradualist strictures (against generalizing too much, too soon) apply only to the formulation of a complete, fully developed general theory of conflict from which all the special theories can be derived. If the task of building a general theory of conflict is properly understood, it can be fruitfully pursued even though special theories are still being revised and tested. Thus, according to Merton (1967, p. 51):

Sociological theory, if it is to advance significantly, must proceed on these interconnected planes: (1) by developing special theories from which to derive hypotheses that can be empirically investigated and (2) by evolving, not suddenly revealing, a progressively more general conceptual scheme that is adequate to consolidate groups of special theories. To concentrate entirely on special theories is to risk emerging with specific hypotheses that account for limited aspects of social behavior . . . but that remain mutually inconsistent.

Applied to the study of social conflict, this suggests that some work toward a general theory of conflict is necessary even while the lower level special theories are still being developed. If the generalist argument is interpreted to mean that special theories will contribute most to scientific advance only when developed in relation to the broader conceptual framework provided by a general theory of conflict, then it is not inconsistent with the gradualist view of scientific progress.

\section{The Need for a General Theory}

So far, I have only shown that the idiographic, specialist, and gradualist objections are at best weak deterrents to the pursuit of a general theory of conflict. On the positive side, there are several reasons for trying to develop at least the conceptual framework of such a theory. First, the formulation of special theories or empirical generalizations covering limited domains implies that a specific class of conflict phenomena is designated as belonging to each domain. Identification of these special classes of phenomena can best be done within a more general framework for the study of conflict. Second, much empirical work and lower level theorizing is already heavily influenced, both implicitly and explicitly, by general theories of social conflict, or at least by general theoretical orientations toward the nature, causes, and consequences of conflict. Since these more general frameworks already exist, explicit attention should be given to testing their conceptual and empirical adequacy, in order to avoid the proliferation of error through repetition of inadequate concepts and assumptions in a series of special theories. Third, the existing diversity of empirical and theoretical approaches to the study of social conflict has produced a state of conceptual and terminological confusion, which impedes both comparisons between distinct classes of conflict phenomena and the process of theoretical integration. A consistent language for discussing conflict phenomena can only be provided by a unified theoretical framework.

\section{DIFFICULTIES IN IDENTIFYING THE}

DOMAINS OF SPECIAL THEORIES

In the absence of a general conceptual framework, the designation of classes of conflict phenomena to be subsumed under separate special theories remains unsystematic. Types of conflict are usually selected for specialized study according to diverse practical and theoretical criteria, which differ from one theorist to another. Consequently, there is no way of knowing how 
many special theories will be or ought to be constructed, nor which types of conflict will be left out of consideration altogether. This ad hoc approach leads to an indeterminate number of special theories with unclear implications for future theoretical integration. A general scheme for classifying conflicts should be able to eliminate this indeterminacy by providing a comprehensive partitioning of the entire domain of social conflict phenomena. However, there are serious difficulties in arriving at a generally accepted taxonomy. These can be illustrated by an analysis of the most common way of classifying conflicts, i.e., classifications based on the nature of the opposing parties.

In the preceding discussion, the domains of various special theories were identified as interpersonal, community, class, political, racial, ethnic, religious, or international conflicts, etc. These types are distinguished according to the nature of the conflicting social units, defined in terms of their institutional locus or the level of social structure which they represent. Underlying this principle of classification is the assumption that each kind of social unit, having its own range of size, structure, and institutions, will also have its own modes of interaction and thus its own patterns of conflict with other social units. On this assumption one could, in principle, construct a complete list of conflict types, each requiring a separate set of generalizations and its own special theory. The first step would be to list all the possible kinds of social units, and the second would be to list all the possible combinations of these kinds of units where conflicts might occur, each distinct combination designating an empirical domain for a special theory of conflict. Such a classification of conflicts would thus be derived from (a) a classification of social units (part of the theory of social structure), and (b) a set of assumptions concerning the possibility of conflicts between sets of two or more like and unlike social units (part of the theory of social conflict).

A systematic procedure of this sort would avoid the indeterminacy inherent in the usual ad hoc designations of empirical domains for special theories of conflict. But it is immediately rendered impracticable by an even more formidable source of indeterminacy, i.e., the absence of a universally accepted taxonomy of social units. Diverse classifications of social units imply diverse classifications of conflicts, and each classification of conflicts implies a different set of special theories. This is reflected in the diversity of previous attempts to classify conflicts according to the nature of the social units involved.

Throughout the 20th century, many social scientists have addressed themselves to the task of developing a general classification of social conflicts. Most of these authors have recognized the nature of the parties as one possible basis of classification, but few have given it a prominent place in their schemes, and even fewer have developed it systematically. Sorokin (1928, p. 327; 1947, p. 96) suggests, as a minor but sometimes useful basis for classification, the nature of the antagonizing units. $\mathrm{He}$ distinguishes first between interpersonal and intergroup antagonisms, and then lists about twenty different kinds of groups which may be parties to intergroup conflicts. But this is merely an illustrative, nonexhaustive list, with no systematic grounds for distinguishing these types: states, nations, nationalities, races, castes, classes, orders, and families; also religious, political, sex, economic, occupational, ethnic, ideological, ethical, artistic, scientific, philosophical, and territorial groups. Ross (1930) gives much 
greater prominence to this mode of classification, devoting separate chapters of his Principles of Sociology to nine types of intergroup conflict, including four of those listed by Sorokin (races, classes, sex groups, and religious groups) and five additional types (conflicts between generations or age groups, town vs. country, learned vs. ignorant, industrial conflict, and intraclass conflict). Mack and Snyder (1957, p. 229) mention individuals, social classes, nations, and groups, and add six more categories (cultures, coalitions, personalities, organizations, organisms, and systems) to the list of possible types of parties. Such lists are frequent in the conflict literature, most writers merely citing an illustrative handful of types, including perhaps one or two not cited by other authors. Collectively, they probably contain the entire social science vocabulary for referring to types of social units, but even if one compiled a complete, unified list, it would not represent a systematic classification. Furthermore, it would generate an inordinate number of partydefined types of conflict, and thus an unwieldy set of special theories.

Some authors have tried to reduce this kind of classification to a manageable system by ordering types of parties according to the levels of social structure which they represent. For example, in an "experiment in integration of knowledge" about techniques of reaching agreement, Chase (1951) presents a classification of levels of conflict:

1. Personal quarrels--husband vs. wife, employer vs. servant, etc.;

2. Family vs. family;

3. Feuds-clan vs. clan;

4. Community quarrels-town vs. town, state vs. state;

5. Sectional quarrels-South vs. North, Southern Ireland vs. Ulster, etc.;

6. Workers against managers-foremen's unions vs. the rest of management, AFL vs. CIO, jurisdictional disputes between trade unions, etc.;

7. Political parties-two or more competing in elections;

8. Conflicts between the races-white vs. black, white vs. yellow, white vs. red, etc.;

9. Religious conflict-Protestants vs. Catholics, Hindus vs. Moslems, Jews vs. Moslems;

10. Anti-semitism-worldwide compound of racial, religious, and cultural antagonisms;

11. Ideological quarrels-communism vs. capitalism, business vs. government, labor vs. capital, communism vs. socialism, etc.;

12. Occupational conflicts-farmer vs. industrial worker, blue-collar vs. white-collar, etc.;

13. Competition within a given industrydenunciation of price-cutters and chiselers;

14. Competition between industries-trucks vs. freight cars, oil vs. coal, silk vs. rayon, etc.;

15. National rivalries-nation vs. nation;

16. Conflicts between cultures-ingroup vs. outgroup;

17. Cold war-Russia and her satellites vs. the democracies;

18. East vs. West.

This brings a semblance of order lacking in the lists previously cited, but it is not derived from an explicit theory of social structure. Furthermore, 18 levels represent a fairly large number of domains for special theories of conflict. But, since Chase does not consider this an exhaustive list, the number implied is even greater, and remains indeterminate.

A more compact classification of structural levels of conflict is presented by LeVine (1961, pp. 4-5):

1. Intrafamily-interpersonal conflict between family members (e.g., sibling rivalry, intergenerational conflict, and husband-wife antagonism);

2. Intracommunity -interpersonal conflict between members of different families within the small local community, and intergroup conflicts (between community factions based on neighborhood, descent, class, caste, or associational ties);

3. Intercommunity-all levels above the single local community but within a single ethnolinguistic entity, the number and identity 
TABLE 1

Damrendorf's Classification of Social Conflicts (Adapted from Angell, 1965)

\begin{tabular}{|c|c|c|c|}
\hline & $\begin{array}{l}\text { Equal } \\
\text { vs. } \\
\text { equal }\end{array}$ & $\begin{array}{l}\text { Superordinate } \\
\text { vs. } \\
\text { subordinate }\end{array}$ & $\begin{array}{l}\text { Whole } \\
\text { vs. } \\
\text { part }\end{array}$ \\
\hline \multicolumn{4}{|l|}{ Social Units } \\
\hline Roles & $\begin{array}{c}1 \\
\text { (family role } \\
\text { vs. } \\
\text { occupational role) }\end{array}$ & $\begin{array}{l}2 \\
\text { (occupational role } \\
\text { vs. } \\
\text { labor-union role) }\end{array}$ & $\begin{array}{c}3 \\
\text { (social personality } \\
\text { vs. } \\
\text { family role) }\end{array}$ \\
\hline Groups & $\begin{array}{c}4 \\
\text { (boys } \\
\text { vs. } \\
\text { girls in } \\
\text { school class) }\end{array}$ & $\begin{array}{c}\mathbf{5} \\
\text { (father } \\
\text { vs. } \\
\text { children) }\end{array}$ & $\begin{array}{c}6 \\
\text { (father } \\
\text { vs. } \\
\text { prodigal son) }\end{array}$ \\
\hline Sectors & $\begin{array}{l}7 \\
\text { (air force } \\
\text { vs. } \\
\text { army) }\end{array}$ & $\begin{array}{c}8 \\
\text { (Manufacturers' } \\
\text { association } \\
\text { vs. }\end{array}$ & $\begin{array}{c}9 \\
\text { (Episcopalian Church } \\
\text { vs. } \\
\text { "high church" }\end{array}$ \\
\hline Societies & $\begin{array}{c}10 \\
\text { (Protestants } \\
\text { vs. } \\
\text { Catholics) }\end{array}$ & $\begin{array}{l}11 \\
\text { (free men } \\
\text { vs. } \\
\text { slaves) }\end{array}$ & $\begin{array}{c}12 \\
\text { (state } \\
\text { vs. } \\
\text { criminal gang) }\end{array}$ \\
\hline $\begin{array}{l}\text { Suprasocietal } \\
\text { relations }\end{array}$ & $\begin{array}{c}13 \\
\text { (Soviet bloc } \\
\text { vs. } \\
\text { Western bloc) }\end{array}$ & $\begin{array}{l}14 \\
\text { (Soviet Union } \\
\text { vs. } \\
\text { Hungary) }\end{array}$ & $\begin{array}{c}15 \\
\text { (Common Market } \\
\text { vs. } \\
\text { France) }\end{array}$ \\
\hline
\end{tabular}

of levels being extremely variable across cultures; examples are conflicts between local communities, between allied clusters of local communities, between cross-community groupings (e.g., lineages, clans, and associations), between autonomous states or chiefdoms, between provinces or chiefdoms within a national organization (or between the latter and the central state);

4. Intercultural-conflicts between groups belonging to different ethnolinguistic entities, or between such entities acting as units (e.g., intertribal conflicts).

This scheme is much more firmly grounded in the theory of social structure, and implies a more manageable number of domains for special theories of conflict. However, there remains a certain amount of indeterminacy in designating these domains, because of the cross-cultural variability in number of levels. Furthermore, LeVine points out (following Siegel and Beals,
1960) that there are also types of "pervasive" conflict which spread to several levels. It is unclear whether these multilevel conflicts would require a single theory or several special theories.

While LeVine's classification is based on an "anthropological" conception of social structure geared to nonindustrial societies, Dahrendorf (1961, cited by Angell, 1965, p. 92) has presented a "sociological" classification geared to industrial societies. It is based not only on the social structural level of the conflict but also on the structural relations between the parties. Angell exhibits the scheme in tabular form, which I have modified slightly, as shown in Table 1. The concrete types named in the cells are merely examples of the more abstract categories implied by the row and column headings. Taken at face value, this scheme 
defines 15 types of conflict, one for each cell, and is the first so far to imply a determinate number of special theories. However, as Angell points out, Dahrendorf further reduces the list by grouping the phenomena (as indicated by the lines) into six main types: role conflicts (top row), competition (cells 4 and 7), "proportion struggle" (cell 10), class conflicts (cells 5, 8, and 11), minority conflict and deviation (cells 6, 9, and 12), and international conflicts (bottom row). This reintroduces indeterminacy in identifying separate empirical domains-should there be only six special theories of conflict, as Dahrendorf seems to suggest, or fifteen special theories as the full table implies?

The nature of the parties also has a prominent place in Boulding's (1962) general theory of conflict, but his classification is not based on levels of social structure. Instead, more abstract, mathematical (especially set theory) conceptions are used to bring other structural dimensions into focus. He first distinguishes three main types of parties: the individual person, the group (unorganized subpopulation within some larger population), and the organization (well-structured group with clearly defined roles and constitution); the latter two consist of sets of persons acting collectively (p. 105). In this scheme, "groups" are simply socially significant "categories" of persons, identified according to characteristics which are either mainly involuntary (e.g., sex, age, race, physical type, family position, kinship, etc.) or mainly voluntary (e.g., religious, social, political, class, civil status, economic, educational, local, national, and organizational role affiliations of the person, etc.). Boulding makes two further distinctions between types of groups: (1) groups which form a strict partition of persons or of time and energy into mutually exclusive subsets vs. overlapping groups to which persons may belong simultaneously; and (2) groups which occupy separate but contiguous regions in some sort of physical or vector space vs. groups which are intermingled throughout a jointly occupied space (pp. 110-13).

Given these basic concepts, together with the notion that the parties to a conflict may be of either the same structural type or different structural types, Boulding distinguishes the following kinds of social conflicts:

1. Conflicts between or among persons;

2. Boundary conflict between groups (spatially segregated groups);

3. Ecological conflict between groups (spatially intermingled groups);

4. Homogeneous organization conflict (i.e., between organizations of like character and purpose, such as state vs. state, sect vs. sect, union vs. union, etc.);

5. Heterogeneous organization conflict (i.e., between unlike organizations, such as state vs. church, union vs. corporation, university vs. church or state, etc.);

6. Conflicts between a person and a group (mainly socialization conflicts, as in child vs. family, person vs. peer group, person vs. hierarchical superiors or inferiors, etc.);

7. Conflicts between a person and an organization (mainly role conflicts).

8. Conflicts between a group and an organization.

By itself, this system implies a small, determinate number of special theories of conflict. But Boulding once again injects indeterminacy by listing several concrete, empirical types of conflict (economic, industrial, international, ideological, and ethical) which cannot simply be subsumed as special cases under the more abstract types. To the extent that these more concrete types are defined in terms of the nature of the parties, they are located on institutional and cultural dimensions which cross-cut the mathematical dimensions used in the more 
abstract classification. For example, industrial conflict (employer vs. employed) can appear under any of the abstract types, since either party can be a person, group, or organization (Boulding, 1962, p. 213). International conflict can fall under either homogeneous or heterogeneous organization conflict, depending on whether the parties (which may be tribes, feudal states, universal agricultural empires, industrial powers, or superpowers) are equal, unequal, or hopelessly unequal (pp. 227-229). The conflict of ideological systems is partly ecological, partly organizational (p. 278). In Boulding's view, these empirical types (which do not represent an exhaustive list) are different enough from each other to require separate treatment. Whether this dual classification implies $8+4$ special theories, $8 \times 4$ special theories, or some intermediate or larger number, is not at all clear.

The mode of abstraction represented in Boulding's eight-type scheme has been carried a step further. One need only distinguish two types of parties-individuals vs. collective entities (e.g., Sorokin's distinction between persons and groups). Similarly, the structural relations between parties can be reduced to a simple dichotomy: either the conflicting parties are members of a larger system or else they are separate, autonomous entities which happen to interact in a common environment. This latter distinction has appeared (under various labels) in many schemes: distinctions such as those between intragroup and intergroup conflict (Simmel, 1955; Coser, 1956), intraparty and interparty conflict (Mack and Snyder, 1957), conflict within a social unit and conflict between social units (Levinger, 1957), or internal conflict ("quandaries") and conflicts between parties (Boulding, 1957), all reflect the same basic dichotomy. By combining these two basic dichotomies, one arrives at a simple classification containing four types of conflict, as illustrated by Galtung (1965b, p. 348), who presents the following table:

$\begin{array}{ccc} & \text { Intrasystem } & \text { Intersystem } \\ \text { conflict } & \text { conflict } \\ \begin{array}{c}\text { Individual } \\ \text { level }\end{array} & \text { intrapersonal } & \text { interpersonal } \\ \begin{array}{c}\text { Collective } \\ \text { level }\end{array} & \text { e.g., intranational } & \text { e.g., international }\end{array}$

By ignoring the differences among concrete types which could appear in the bottom row, this table implies a smaller number of special theories than any scheme so far discussed.

Galtung's four-cell scheme is not merely a condensation of Boulding's eight abstract types, but rather a partial condensation combined with the addition of new types. On one axis (nature of parties), Galtung has simply ignored Boulding's distinction between groups and organizations, replacing these with a single category, i.e., "collectivities." Furthermore, he ignores the distinction between homogeneous and heterogeneous pairs of parties. The result is that one of Boulding's types of conflict (interpersonal) is retained in Galtung's scheme, while the remaining seven types are apparently subsumed under a single category (intersystem, collective level). Thus Galtung's scheme reduces Boulding's eight types to only two by ignoring certain distinctions. On the other axis (structural relations between parties), Galtung introduces new types by attending to an aspect (intrasystem vs. intersystem) which is at best only implicit in Boulding's scheme. Thus intrapersonal conflict is not one of Boulding's eight types (even though he does discuss intrapersonal conflict as a factor which influences the behavior of indi- 
viduals in conflict with each other). Similarly, intracollectivity conflicts are not explicitly included in Boulding's scheme (even though elsewhere he does treat them as "internal" conflicts). One might wish to construe two of Boulding's types (person vs. group, person vs. organization) as "intrasystem" conflicts, but this would not be consistent with Galtung's meaning:

By an intra-system conflict . . . we mean a conflict that can be found in the smallest subunits of the system, down to the individual actor, whereas an inter-system conflict splits the system in parts, each subsystem standing for its own goal state [Galtung, 1965b, p. 348].

Clearly, in the scheme discussed here, Boulding's analysis treats the parties as having separate, incompatible goals rather than as sharing ambivalences or quandaries, and this fits Galtung's definition of "intersystem" conflicts.

Taken together, these systematic partybased classifications presented by Chase, LeVine, Dahrendorf, Boulding, and Galtung fail to overcome the difficulties inherent in less systematic approaches. First, any particular type of conflict may be prominent in one scheme, secondary in another, and ignored in still others. For example, "interpersonal" conflict is prominent in Galtung's scheme (one of four main types) and in Boulding's mathematically oriented scheme (one of eight main types); it is less prominent but still treated as a separate type in Chase's scheme (one of 18 or more main types). Given the assumption that each main type requires a special theory, these schemes all imply that a special theory of interpersonal conflict should be constructed. However, the remaining schemes do not: LeVine states that interpersonal conflicts constitute all of one main category (intrafamily) but also part of another (intracommunity), so that a single special theory of interpersonal conflict is not indicated; Boulding's institution-centered classification has interpersonal conflicts distributed through several main types (economic, industrial, ideological, and ethical); and Dahrendorf's scheme does not explicitly deal with interpersonal conflicts, although one might guess that these would occur mainly at his "group" level. Similarly, "class" conflict appears as one of six main types in Dahrendorf's condensed scheme, but is treated by Boulding as merely a special case of "economic" conflicts and by LeVine as merely a special case of "intracommunity" conflicts, and is not explicitly mentioned by Chase or Galtung. The same applies to numerous other kinds of conflict that appear in one or more of these classifications. Second, the total number of main types of conflict varies considerably from scheme to scheme, ranging from four (Galtung) to 18 or more (Chase). This means that the indeterminacy in specifying domains for special theories is even greater when all schemes are taken together than it is when each is considered by itself. Third, even when two schemes list the same number of types, the specific types listed are usually quite different. For example, one could consider LeVine's four levels of conflict (intrafamily, intracommunity, intercommunity, intercultural) as four main types requiring special theories. But these types are clearly not identical with the four distinguished by Galtung (intrapersonal, interpersonal, intracollectivity, intercollectivity), and probably cover only the phenomena included in his two "intersystem" categories. Similarly, although Dahrendorf's 15-cell scheme provides almost as many types as Chase's 18 levels, and there is some overlap between the two lists, nevertheless each scheme includes several types not included by the other. 
Furthermore, even a master list of all the distinct types of conflict that appear in these several schemes taken together would not solve the problem. Such a list would have the same drawback as noted earlier in the case of unsystematic classificationscombining those schemes which have nonexhaustive lists of relatively concrete types (Chase's 18 types, LeVine's eight or more levels, and Boulding's four institutionallydefined types) could only yield a long and incomplete list, implying an unwieldy number of special theories. Likewise, while a combination of the more abstract schemes (Dahrendorf's 15 types, Boulding's eight types, and Galtung's four types) might yield an exhaustive list (i.e., a complete partition of the total domain of social conflict phenomena into mutually exclusive subsets), this could not be done systematically without distinguishing a very large number of types. Simply adding to one scheme each type from the others that the first does not mention would produce a list of less than 27 types $(15+8+4$, minus all duplication). But, this would leave out many kinds that are obviously implied by the schemes in question. One could not simply add Galtung's two categories of intrapersonal and intracollectivity conflicts to Boulding's list of interunit types, or to the combined Dahrendorf-Boulding list. Instead, Galtung's intrasystem vs. intersystem distinction would have to be applied systematically to each kind of social unit (roles, persons, groups, sectors, organizations, societies, and suprasocietal units), thus doubling the number of conflict types distinguished. Similarly, Boulding's distinction among persons, groups, and organizations, which is based on degree of collective organization, cannot simply be added to Dahrendorf's typology of social units, which is based on levels of social structural inclusiveness. In general, because they are based on different dimensions, these schemes can be combined systematically only by multiplication rather than by simple addition of types. The result would imply a very large number of special theories of conflict.

It thus becomes apparent that even in the hands of theorists with a generalist approach, party-based classifications of conflict do not yet provide an accepted designation of the empirical domains for special theories of conflict. In order to arrive at a satisfactory list, we would first have to reach agreement on a classification of social units-by choosing among existing schemes, or by providing a conceptual integration of existing schemes, or by developing an entirely new scheme.

But even if a complete and generally accepted party-based classification of conflicts could be achieved, it would not necessarily provide the best basis for distinguishing types of conflict that require special theories. The choice of such a classification, as noted earlier, is based on the assumption that conflicts involving one kind of social unit are different in principle from conflicts involving other kinds of social units. To be sure, there are some good reasons for accepting this assumption: LeVine argues that as one moves up to higher levels of social structure, increasingly formal and legalistic mechanisms for controlling or resolving conflicts are used; Dahrendorf argues that the nature of the issues or of the underlying conflict of interest, as well as the nature of the conflict process, depends upon the social structural origins of the parties; and Boulding argues that both the psychological structure and the behavioral dynamics of a conflict depend on the internal and external organization of the parties. But these arguments support only the view that the nature of the parties is 
an important variable which must be included in a general theory of conflict. They do not support the considerably stronger assumption that it is the most important variable and should therefore be used to establish boundaries between the domains of special theories.

In addition, there are several reasons for thinking that the nature and sociocultural locus of the parties is not the most fundamental basis for classifying conflicts. First, although this is the most common way of designating special types in nontheoretical discussions, the great majority of systematic general classification schemes either ignore it or implicitly assign it a minor role. Second, a number of writers argue explicitly that the nature of the parties is much less important than other variables, such as the socially integrative or disruptive character of the conflict (Simpson, 1937, p. 41), the logical structure of the conflict situation (Rapoport, 1965, p. 206), or the intensity, degree of regulation, and realism-neuroticism of the conflict (Stagner, 1967, pp. 139ff). Third, even Boulding, who attributes great importance to the nature of the parties, actually begins with other variables in designating special types of conflict. Noting that "there is not a single concept of conflict, and therefore there cannot be a single theory of conflict," he distinguishes three different conflict situations ("economic" or "issue" conflicts, "interaction" conflicts or "Richardson processes," and "internal" conflicts or "quandaries") according to their differing psychological and behavioral dynamics (Boulding, 1957, pp. 131-33). Later, in Conflict and Defense (1962), before dealing with the nature of the parties he first presents a series of highly abstract models for various patterns of conflict, i.e., a series of special theories for psychologically and behaviorally defined types of conflict. Fourth, and last, it can be argued that because all social units at any sociocultural locus involve human beings, and since human nature must remain the same regardless of specific institutional contexts, there is as much reason to think that different kinds of social units will behave according to the same principles as there is to think that they will behave according to fundamentally different principles. One might therefore do better by using variables other than the nature and sociocultural locus of the parties to distinguish types of conflict that require special theories.

This means that further work on the general theory of conflict is necessary before an adequate set of special theories can be developed. As I will show later, the diversity among classifications based on other aspects of conflict far exceeds the diversity among party-based classifications. A large number of variables, describing the psychological and behavioral causes, course, and consequences of conflicts, have been used in various combinations to define a very large and heterogeneous assortment of conflict types. Any attempt to describe, compare, and either choose among or integrate these various classification schemes will take considerably more effort than would be required in the case of the partybased classifications reviewed above. Furthermore, we still do not have satisfactory criteria for deciding which of these additional variables are important enough to serve as the source of parameters defining the domains of special theories. Although the development of such criteria may require a certain amount of comparative empirical study of different kinds of conflict, it nevertheless depends in part on further development of the general theory of social conflict. 


\section{IMPACT OF GENERAL FRAMEWORKS}

ON SPECIALIZED STUDIES

Even if they do not yet provide an acceptable taxonomy of conflicts, existing general frameworks do influence the formulation of special theories and the design of related empirical investigations. The need to examine and control that influence is perhaps an even more important reason for attempting to advance the general theory of social conflict. The pervasive impact of general theories of conflict on specialized conflict research can be demonstrated in a number of ways.

In the first place, it must be recognized that general theories of social conflict (or at least conceptual frameworks, assumptions, and hypotheses oriented to the analysis of conflict in general) have been around for a long time, both in the social sciences and in the general culture. General orientations toward conflict are present in all cultures, and appear not only in social science but also in religious, ethical, political, and philosophical systems from Heraclitus to Hegel, Machiavelli to Hobbes, and Locke to Mill (Sorokin, 1928, 1947, 1966; K. Singer, 1949a, 1949b; Bernard, 1957b) . Several writers trace the beginnings of the modern sociology of conflict back to Marx and to Social Darwinists like Bagehot, Gumplowicz, Ratzenhofer, and Oppenheimer (Sorokin, 1928; Bernard, 1950; Coser, 1956, 1967; Dahrendorf, 1959, 1967; Horowitz, 1962). As Angell (1965) has argued, these early sociological theories were not truly general since they did not deal with all forms of social conflict. Nevertheless, these theories (along with the theories of Pareto, Durkheim, Marshall, Weber, Freud, and many others) contain many concepts, assumptions, and hypotheses which greatly influenced later writers who did attempt to deal with conflict in general. By the late 19th century, highly general theories of conflict in physical, biological, and social systems were presented in such works as Conflict in Nature and Life (Patterson, 1883), Les Luttes Entre Sociétés Humaines et Leurs Phases Successives (Novicow, 1896), and L'Opposition Universelle (Tarde, 1897). General theories of social conflict appeared in the works of Tarde (1899), Simmel (1903), Carver (1908, 1915) and others. Various mixes of these and earlier theories, together with new contributions and applications of these theories to various kinds of social conflict, appeared in the general sociologies of such writers as Cooley (1918), Park and Burgess (1924), Ross (1930), Von Wiese and Becker (1932), MacIver (1937), Lundberg (1939), and Sorokin (1947), and in general treatments of conflict by Lasswell (1931), Simpson (1937), Lewin (1948), K. Singer (1949b, 1949c), Wright (1951), Chase (1951), Lawner (1954), and Coser (1956), among others.

Again, various combinations of concepts, assumptions, and hypotheses from these earlier theories, together with game theory and other mathematical approaches, continue to dominate the general theories of conflict developed by such writers as Bernard (1954, 1957a, 1957b, 1960, 1965), Mack and Snyder (1957), Boulding (1957, 1962), Dahrendorf (1958, 1961), Schelling (1958, 1960), Rapoport (1960, 1965), Galtung (1959, 1964, 1965a, 1965b), Rex (1961), DeKadt (1965), Thurlings (1965), Beals and Siegel (1966), Coser (1967), and Stagner (1967). It is difficult to see how such diverse views on conflict in general, persisting over such a long time, could fail to influence both the general education and the specific investigations of those who specialize in the analysis of particular kinds of social conflicts. 
TABLE 2

Three Approaches to the Analysis of Social Conflict (From Bernard, 1957b)

\begin{tabular}{|c|c|c|c|c|}
\hline & & Social-psychological & Sociological & Semanticist \\
\hline & $\begin{array}{l}\text { Basis or starting } \\
\text { point of conflict }\end{array}$ & $\begin{array}{l}\text { tensions within the } \\
\text { individual which } \\
\text { result from accumu- } \\
\text { lated frustrations and } \\
\text { can be relieved only } \\
\text { through aggression; } \\
\text { essentially nonrational }\end{array}$ & $\begin{array}{l}\text { incompatibility } \\
\text { between the goals, } \\
\text { aims, or values of } \\
\text { the opposing systems } \\
\text { (individuals or } \\
\text { groups); often } \\
\text { rational }\end{array}$ & $\begin{array}{l}\text { verbal or conceptual } \\
\text { misunderstanding } \\
\text { between the parties; } \\
\text { nonrational; goal or } \\
\text { value incompatibility } \\
\text { does not exist }\end{array}$ \\
\hline & $\begin{array}{l}\text { Orientation toward } \\
\text { the opponent }\end{array}$ & $\begin{array}{l}\text { prejudice, hostility, } \\
\text { hatred, stereotypes }\end{array}$ & $\begin{array}{l}\text { hatred and hostility } \\
\text { not necessarily } \\
\text { present }\end{array}$ & $\begin{array}{l}\text { hatred and hostility } \\
\text { present }\end{array}$ \\
\hline & $\begin{array}{l}\text { Modes of action } \\
\text { or of resolution }\end{array}$ & $\begin{array}{l}\text { scapegoating, } \\
\text { aggression, fighting, } \\
\text { quarreling, violence; } \\
\text { efforts to change } \\
\text { attitudes or motives }\end{array}$ & $\begin{array}{l}\text { schism, secession, civil } \\
\text { war, sect formation, } \\
\text { splinter parties, } \\
\text { resistance movements, } \\
\text { revolutions, reform } \\
\text { movements; strategic } \\
\text { considerations }\end{array}$ & $\begin{array}{l}\text { breakdown in } \\
\text { communication; } \\
\text { efforts at semantic } \\
\text { clarification }\end{array}$ \\
\hline
\end{tabular}

In the second place, certain theoretical frameworks can be identified as alternative approaches to a wide variety of special kinds of conflict phenomena. For example, Jessie Bernard (1957b) distinguished three general frameworks which she called the "social psychological" or "tensions" approach, the "sociological" or "cost" approach, and the "semanticist" or "misunderstandings" approach. These approaches differ in the general assumptions they make about the causes, nature, and resolution of conflicts. Bernard's characterization of these three frameworks is briefly summarized in Table 2. Bernard showed how these competing approaches have been applied in specialized research on interpersonal conflicts, conflicts between racial, ethnic, or religious groups, industrial conflicts, community conflicts, class conflicts, political conflicts, wars, and other large-scale conflict phenomena.

A similar set of distinctions is made by Rapoport (1960) in his effort to characterize the crucial differences between three intellectual frameworks for analyzing social conflicts. He distinguishes three modes of conflicts ("fights," "games," and "debates") according to psychological and behavioral patterns characteristic of each. These are not empirical classes of conflict phenomena, but rather ideal types representing three different sets of general assumptions about the structure and dynamics of conflict situations (see Table 3).

Rapoport groups theories of conflict under these three headings according to the underlying assumptions of each theory. Under the heading of fights he mentions psychological theories of aggression and discusses "social physics" models of mass behavior which ignore rationality of the parties; examples are Richardson's (1960a, 1960b) mathematical theories of "arms races," "deadly quarrels," and "war mood epidemics," economic models of social exploitation (parasitism), and various biomathematical theories of ecological competition ("struggle for existence"). Under games, he discusses game theory and decision theory, and Schelling's (1960) elaboration on these, which assume the rationality of the parties. 
TABLE 3

Three Models of Conflict Dynamics (From Rapoport, 1960)

\begin{tabular}{|c|c|c|c|c|}
\hline & & Fights & Games & Debates \\
\hline & $\begin{array}{l}\text { Basis or starting } \\
\text { point of the } \\
\text { struggle }\end{array}$ & $\begin{array}{l}\text { mutual fear or } \\
\text { hostility between } \\
\text { the parties }\end{array}$ & $\begin{array}{l}\text { agreement between } \\
\text { the parties to strive } \\
\text { for mutually incom- } \\
\text { patible goals within } \\
\text { constraint of certain } \\
\text { rules, but not where } \\
\text { outcome can be } \\
\text { predicted in advance }\end{array}$ & $\begin{array}{l}\text { disagreement between } \\
\text { the parties about } \\
\text { "what is" (facts) or } \\
\text { "what ought to be" } \\
\text { (values); i.e., clashes } \\
\text { of convictions or } \\
\text { "outlooks" }\end{array}$ \\
\hline 2. & $\begin{array}{l}\text { Image of the } \\
\text { opponent (held } \\
\text { by each party) }\end{array}$ & $\begin{array}{l}\text { mainly a nuisance; } \\
\text { preferably, the } \\
\text { opponent should dis- } \\
\text { appear, or at least } \\
\text { be reduced in size } \\
\text { or importance }\end{array}$ & $\begin{array}{l}\text { an essential partner, } \\
\text { seen as a mirror } \\
\text { image of the self; } \\
\text { preferably, a strong } \\
\text { opponent who will } \\
\text { do his best to win; } \\
\text { a rational being } \\
\text { whose inner thought } \\
\text { processes must be } \\
\text { taken into account }\end{array}$ & $\begin{array}{l}\text { (mistaken or mis- } \\
\text { guided; preferably, } \\
\text { the opponent should } \\
\text { become a convert to } \\
\text { one's own outlook) }\end{array}$ \\
\hline 3. & $\begin{array}{l}\text { Obiective of } \\
\text { each party }\end{array}$ & $\begin{array}{l}\text { harm, destroy, subdue, } \\
\text { or drive away the } \\
\text { opponent }\end{array}$ & outwit the opponent & $\begin{array}{l}\text { convince the opponent } \\
\text { (or some bystander) }\end{array}$ \\
\hline 4. & $\begin{array}{l}\text { Mode of } \\
\text { interaction }\end{array}$ & $\begin{array}{l}\text { nonrational series of } \\
\text { actions and reactions } \\
\text { to the other's and } \\
\text { one's own actions; } \\
\text { use of thrusts, } \\
\text { threats, violence, } \\
\text { etc.; course does } \\
\text { not depend on goals } \\
\text { of the opponents }\end{array}$ & $\begin{array}{l}\text { parties cooperate by } \\
\text { following the rules } \\
\text { and by doing their } \\
\text { best to provide } \\
\text { maximum challenge } \\
\text { to the opponent; } \\
\text { actions (stratagems) } \\
\text { chosen on basis of } \\
\text { probable outcomes; } \\
\text { strategic logic; } \\
\text { terminates when } \\
\text { outcome is obvious } \\
\text { to both sides }\end{array}$ & $\begin{array}{l}\text { verbal interaction in } \\
\text { which parties direct } \\
\text { arguments at each } \\
\text { other; use of various } \\
\text { techniques of persua- } \\
\text { sion such as brain- } \\
\text { washing, explaining } \\
\text { away the opponent's } \\
\text { beliefs, and removing } \\
\text { threats associated in } \\
\text { the opponent's mind } \\
\text { with adopting one's } \\
\text { own outlook }\end{array}$ \\
\hline
\end{tabular}

“Debates" deals primarily with nonrational (emotionally and ethically oriented) techniques of persuasion based on Pavlovian, Freudian, and Rogerian outlooks, with emphasis on the last of these.

Though similar to Bernard's classification of conflict theories, Rapoport's scheme differs in certain important ways. First, although his "debate" model is derived from a General Semantics background, it deals with conflicts based on disagreements rather than on misunderstandings, and suggests considerably different processes than the "semanticist" approach. Second, although the definition of "fights" (emphasizing nonrational hostility and aggression) is consistent with the "social-psychological" approach, the former subsumes a number of theories which the latter does not. Several of the theories discussed by Rapoport under "fights" are treated by Bernard as instances of the "sociological" approach (e.g., theories of social exploitation), or else as theories of "competition" (e.g., arms races, ecological competition) rather than of "conflict" (Bernard, 1960). 
In a more recent review, Bernard (1965) presents a modified classification of theoretical approaches which corresponds more exactly to Rapoport's trichotomy. Viewing theories of conflict historically, she treats the various frameworks as competing "paradigms" (Kuhn, 1962). The key distinction is that between "rationalistic" and "nonrationalistic" models, a fundamental polarity in the history of Western thought. In the 1940 s, the dominant theories of conflict reflected the nonrationalistic "social-psychological" or "tensions" approach, which was then challenged by the emergence of the rationalistic game theory (strategic) approach. During the past decade, three theoretical responses to the challenge of game theory have appeared. Bernard calls these: (1) the "neo-strategic model" (Schelling's [1958, 1960] transformation of game theory into a theory of social interaction); (2) the "nonstrategic model" (Richardson's arms-race models as modified by Rapoport [1960] and Boulding [1962]); and (3) the "anti-strategic model" (Rapoport's debate model). The first of these is rationalistic, and corresponds to "games"; the latter two are nonrationalistic and antirationalistic, corresponding respectively to "fights" and "debates." Thus, despite differences in labeling, Bernard and Rapoport have identified the same three general approaches to the analysis of various kinds of social conflict.

In the third place, it is easy to show that particular theories or hypotheses about conflict in general have been applied to various types of conflict by different authors. For example, Simmel (1903, 1955) stated a number of hypotheses about the positive social functions of conflict, hypotheses which have been repeated or reformulated in general discussions of conflict by several writers from Ross to Coser. These hypotheses have also been applied in discussions or studies of various special types of conflict, such as competition between small groups (J. E. Singer et al., 1963), religious, racial, or ethnic intergroup conflicts (Hager, 1956; Dodson, 1958, 1960; Hines, 1966), industrial conflicts (Kerr, 1954; Dubin, 1957; Friedland, 1961), ritual conflicts in African societies (Gluckman, 1954, 1955), intertribal war in Brazil (Murphy, 1957), international conflicts (North, Koch, and Zinnes, 1960; Rosenau, 1964; Timasheff, 1965), and many others. Or one could cite numerous applications of Freudian theory, general semantics, decision theory, and other specific theories, to conflicts ranging from interpersonal quarrels to world wars.

Thus it is clear that each of several general orientations, approaches, models, theories, and hypotheses has already been widely used in the analysis of various special types of conflict. Wherever they are applied, one can view them either as competing (i.e., as alternative ways to account for the same facts) or as complementary (i.e., as potentially compatible perspectives, each highlighting a different aspect of the phenomena under investigation). For example, Bernard (1957b) regarded the "semanticist," "social-psychological," and "sociological" approaches as competing, and argued for the general superiority of sociological ("strategic," "cost," "game") models, especially as an approach to all kinds of intergroup conflicts. On the other hand, Rapoport (1960), though inclined to prefer the "fight" and "debate" models for large scale intergroup conflicts, treats them and the "game" models as complementary, and argues that an adequate theory of conflict will take into account the various factors emphasized in all three models. In either case, the question of the relevance and 
validity of these general frameworks is already inextricably involved in efforts to develop and test special theories for most kinds of social conflict. Given this pervasive impact of general theories, it seems imperative that they be given explicit attention in any special domain, and that there be constant critical interaction between the two levels of theory construction.

\section{CONCEPTUAL AND}

\section{TERMINOLOGICAL CONFUSIONS}

A third major reason for working toward a general theory of social conflict is the unsatisfactory state of the social scientific language for discussing conflict. As in other problem areas, the conflict literature is characterized by a great diversity of terms and concepts for designating and describing the phenomena under investigation. Both general and special theories differ widely in their definitions and usage of such terms as "conflict," "competition," "tensions," "disputes," "opposition," "antagonism," "quarrel," "disagreement," "controversy," "violence," "nonviolence," "conflict resolution," "mode of resolution," etc. The situation is similar to that described by Biddle and Thomas (1966) in their analysis of the conceptual framework of role theory:

One encounters a bewildering profusion of labels and ideas and a disconcerting absence of agreement among experts concerning the definitions of terms. When the ideas are examined closely ... they will not be found to comprise a complete inventory, nor will all be denotatively precise. These problems of language usually become problems of thought. Imprecise terms lead to fuzzy thinking, and a limited battery of concepts means that an arbitrarily selected portion of the world will be set apart for analysis, with the remainder being ignored. Theory, research, and application alike are adversely affected by these problems of language [p. 21].
Biddle and Thomas go on to point out that a sizable portion of the role literature has been addressed to these terminological difficulties, and that there have been many appeals for terminological and conceptual clarification, as well as some concerted efforts in that direction, but without much real progress (except for their own contribution, which appears to be a genuine advance). The same can be said for the conflict literature. Numerous authors have pointed out the vagueness, ambiguity, and multiple uses of key terms such as "struggle for existence" (Sorokin, 1928), "culture conflict" (Price, 1930), "opposition" (Von Wiese and Becker, 1932), "conflict" (K. Singer, 1949b; Wright, 1951; Coser, 1956, 1964; Mack and Snyder, 1957; Bernard, 1957a; Boulding, 1957), “tension" (Bernard, 1957b), "religious conflict" (Coleman, 1956), "role conflict" (Biddle, Twyman and Rankin, no date), "competition" (Friedsam, 1964), "violence" and "nonviolence" (Sharp, 1959; Galtung, 1965a), "revolution" (Tanter and Midlarsky, 1967), and many others. Some appeals for clarification take the form of a suggestion that a given term is too indefinite denotatively or has too many unwanted connotations to be scientifically useful, and should be replaced by more precise terms (Price, Von Wiese and Becker, Bernard). Other appeals take the form of an insistence on restricting a particular term to one of its several denotative meanings (Sorokin, Wright, Mack and Snyder). This latter approach is sometimes coupled with an extensive effort to rid the term of inappropriate connotations (Coser). However, efforts at clarification more frequently involve the elaboration of a typology of the phenomena usually subsumed under the broader meanings of the term (Boulding, Bernard, Coleman, Biddle et al., Sharp, Galtung, Tanter and Midlarsky). 
These appeals for and efforts at clarification have not led to an internally consistent and generally accepted language for discussing social conflict phenomena. For the most part, they are piecemeal approaches, each focusing on only a small segment of the total theory of conflict, usually ignoring and sometimes contradicting the efforts at clarification made by other authors. Such an approach is bound to fail because the inevitable interdependence among the various terms of a theory requires that they be defined in mutually consistent ways. But no comprehensive, integrated effort at conceptual clarification has yet been made. Most theorists therefore continue to follow the usual practices of offering specific definitions for key terms (simply in order to construct a coherent theoretical system, or to maintain consistency and clarity within the context of a particular discussion) and of choosing terms with the "right" connotations to refer to particular phenomena or concepts.

But these practices are also inadequate, since different theorists persist in having different preferences with respect to terms and definitions. While this raises no problems within each theory, it does create difficulties in comparing, choosing among, or integrating different theories. This is especially true in the conflict literature, which depends heavily on the common language with its rich but vague and ambiguous conflict vocabulary. A finite number of conflict-relevant terms is linked to a finite (but probably larger) number of conflict-relevant concepts. But the relations among these terms and concepts are not invariant. As I will show in more detail later, conceptual diversity (alternative definitions for the same term) combined with terminological diversity (alternative labels for the same concept) often results in contradictory patterns of usage. Sometimes a given pair of terms may be synonymous; in other contexts they may refer to sharply distinguished, coordinate categories; and in still other contexts, the first may denote a special case of the second, or vice versa. For example, conflict as defined by Stagner (1967) is synonymous with competition as defined by Doob (1952); many other writers treat conflict and competition as distinct species of struggle (e.g., Williams, 1947; Mack and Snyder, 1957; Timasheff, 1965); but sometimes competition is regarded as a species of conflict (Simmel, 1955; Dahrendorf, 1961), or conflict is regarded as a species of competition (Lasswell, 1931; Boulding, 1962). Similar shifting relationships occur for many other pairs of terms, such as rivalry and competition, opposition and antagonism, tension and conflict, opposition and conflict, etc.

The resulting terminological and conceptual confusion may simply reflect the fact that scientific knowledge about social conflict has not yet moved to a level of analytical precision superior to that of common sense knowledge. But it may also constitute an impediment to scientific communication and to the advance of knowledge which such communication is supposed to facilitate. Terminological diversity can mask conceptual unity, or it can reflect an underlying conceptual difficulty. Conceptual diversity may reflect divergent aims, divergent assumptions, or divergent factual bases for theory construction, which can be obscured by the use of similar terminology. Whether these are mild annoyances or serious impediments, it seems obvious that a consistent language for discussing conflict phenomena is desirable. Such a language can only be developed within a unified conceptual framework for dealing with conflict in general. 


\section{THE CASE FOR A BROAD CONCEPTION OF SOCIAL CONFLICT}

In arguing the case for a generalist approach to the study of social conflict, I have focused on two main considerations: the inadequacy of a strictly specialist approach for grappling with certain key theoretical problems; and (2) the disagreement among and/or the inadequacy of existing general frameworks relative to the same problems, as indicated by the diversity of terms, concepts, models, and classifications already discussed. As a first step in moving toward a more unified, and hopefully a more adequate general framework, it is now essential to examine more closely some of the conceptual and terminological confusions which appear at crucial points of theory construction in this field.

Fundamental to the whole enterprise is the ambiguity of the term "social conflict," since definitions of this term serve to specify, among other things, the domain of the theory. Presumably, all general theories of conflict have the same domain, their claims to generality resting on their applicability across all kinds of parties or to any sociocultural locus where conflict phenomena may occur. But since theorists differ widely in their conceptions of what constitutes conflict, theories which are equally general with respect to types of parties may nevertheless have quite different ranges of application with respect to types of psychological and behavioral patterns. Such differences are crucial because they affect the comparability of general theories, the classification of conflict phenomena, the logical relations between general and special theories, and the relevance of various bodies of data to the testing and further development of a general theory.

\section{Narrow vs. Broad Definitions}

The range of conceptual alternatives is illustrated by the contrasting positions of Mack and Snyder (1957), who argue for a relatively narrow definition of conflict, and Dahrendorf (1959), who argues for a much broader definition. Reviewing previous approaches, Mack and Snyder state their case as follows:

Given the pervasiveness of conflict phenomena and the diversity of approaches to inquiry, it is legitimate to ask whether the apparent intellectual disorder reflects an inherently incoherent focus of social analysis-a focus artificially created by a label. . . . Obviously, "conflict" is for the most part a rubber concept, being stretched and molded for the purposes at hand. In its broadest sense it seems to cover everything from war to choices between icecream sodas or sundaes. At any rate, the distinctions between conflict and non-conflict are fuzzy at best and at worst are not made at all. ... Relatively little effort has been made to specify analytically different properties of conflict as a generic phenomenon and to differentiate explicitly between conflict and closely related concepts [pp. 212-13].

In order to prevent the concept from becoming too inclusive, they argue, it is necessary to make certain distinctions which are apparently agreed upon or at least commonly made in the literature:

Competition is not regarded as conflict or a form of conflict, though it may be an important source of the latter. ... . The following are also considered differentiable: antagonistic interests, misunderstandings, aggressiveness, hostility or hostile sentiments, desire or intention to oppose, social cleavages, logical irreconcilability of goals or interests, tensions, and rivalry. The attitudes, behaviors, and states of affairs signified by these terms may be among the underlying sources of conflict. Or such factors may accompany or intensify conflict. But it seems generally agreed that none of these terms is a proper synonym for conflict, nor are the 
factors denoted singly or in combination sufficient preconditions of social conflict [p. 217].

Having established what is not considered to be conflict, they proceed to list a set of properties which are present in all social conflicts:

1. At least two parties (or analytically distinct units or entities) having some minimum degree of "contact" with and "visibility" to each other;

2. Mutually exclusive and/or mutually incompatible values and opposed values, based on "resource scarcity" or on "position scarcity";

3. (a) Behaviors designed to destroy, injure, thwart, or otherwise control another party or parties, and (b) a relationship in which the parties can gain (relatively) only at each other's expense;

4. Mutually opposed actions and counteractions; and

5. Attempts to acquire power (i.e., to gain control of scarce resources and positions) or to exercise power (i.e., to influence behavior in certain directions), or the actual acquisition or exercise of power (pp. 21719).

Thus, according to Mack and Snyder, a conflict is a particular kind of social interaction process or "interaction relationship" between parties who have mutually exclusive or incompatible values. Dahrendorf (1959) explicitly rejects such a narrow conception:

Some authors prefer to describe antagonisms and tensions which are not expressed in manifest struggles in terms other than conflict. Thus, they distinguish conflicts and tensions, conflicts and disputes, conflicts and contests, or-most frequently-conflict and competition. ... However ... I am using the term "conflict" in this study for contests, competitions, disputes, and tensions as well as for manifest clashes between social forces. All relations between sets of individuals that involve an incompatible difference of objective-i.e., in its most general form, a desire on the part of both contestants to obtain what is available only to one, or only in part-are, in this sense, relations of social conflict. The general concept of conflict does not as such imply any judgment as to the intensity or violence of relations caused by differences of objective. Conflict may assume the form of civil war, or of parliamentary debate, of a strike, or of a well-regulated negotiation [p. 135; italics added].

In effect, this definition drops properties 3a, 4, and 5 from Mack and Snyder's list. It thus broadens the meaning of conflict on at least two dimensions: first, it extends the terms to include not just one kind but all kinds of antagonistic interaction; second, it extends the term to include situations (which Dahrendorf calls "latent" conflicts) that do not at the moment involve any form of active opposition. By focusing on the psychological aspects and eliminating overt struggle as a criterial attribute, Dahrendorf considerably enlarges the range of phenomena to which the term applies. A theory of "conflict" as Dahrendorf defines it will therefore be much more general than a theory of "conflict" as defined by Mack and Snyder.

One gets the impression from Mack and Snyder that the overwhelming weight of scientific opinion supports their narrower definition. Indeed, an old and prominent sociological tradition does lie behind their conception of conflict as one species of struggle. This is reflected in numerous influential textbooks (e.g., Park and Burgess, 1924; Cooley, 1930; Ross, 1930; Von Wiese and Becker, 1932; Lundberg, 1939; Ogburn and Nimkoff, 1942; Bernard, 1949; Davis, 1949; Young, 1949; and many others); in major reference works such as the Encyclopedia of the Social Sciences (Lasswell, 1931; Hamilton, 1931), Zadrozny's Dictionary of Social Science (1959), and UNESCO's Dictionary of the Social Sciences (Coser, 1964; Friedsam, 1964); 
and in both general and special theoretical or review essays (e.g., Williams, 1947; Wright, 1951; Kerr, 1954; Coser, 1956, 1967; Bernard, 1957a, 1960; Boulding, 1957; Angell, 1965; Mack, 1965; Timasheff, 1965; Gross, 1966; and many others).

However, the impression that this is the generally accepted view contradicts the actual history of social scientific thought on the subject. Many writers explicitly subsume as forms of conflict most or all of the phenomena excluded by Mack and Snyder but included by Dahrendorf (Carver, 1908, 1915; MacIver, 1937, 1942; Simpson, 1937; Weber, 1947; Chase, 1951; Simmel, 1955; Lawner, 1956; Levinger, 1957; Aubert, 1963; Beals and Siegel, 1966; Nicholson, 1967; and many others). Furthermore, broad conceptions of conflict which are more or less consistent with Dahrendorf's definition have been presented by such writers as Schelling $(1958,1960)$, Rapoport (1960), Rex (1961), Boulding (1962), Berelson and Steiner (1964), Galtung (1965b), Thurlings (1965), Johnson (1966), Loomis (1967), and Stagner (1967). Dahrendorf's broader definition of conflict thus appears to be backed by an equally old and equally prominent conceptual tradition.

\section{CONFLICT VS. LATENT ANTAGONISMS}

One main issue raised by the contrast between these conceptions is the question of whether or not strictly psychological antagonism, unaccompanied by overt struggle, should be considered a form of conflict. Among those who favor excluding such situations, Mack and Snyder cited Williams (1947), Wright (1951), Kerr (1954), and Coser (1956). Coser's argument is typical:

A distinction between conflict and hostile sentiments is essential. Conflict, as distinct from hostile attitudes or sentiments, always takes place in interaction between two or more persons. Hostile attitudes are predıspositions to engage in conflict behavior; conflict, on the contrary, is always a trans-action. ... Such predispositions do not necessarily eventuate in conflict; the degree and kind of legitimation of power and status systems are crucial intervening variables affecting the occurrence of conflict [pp. 37-38].

\section{Similarly,}

It is necessary to distinguish between conflict and antagonistic interests arising out of the respective positions of persons or groups within the social structure. Given [their] respective roles, ... the interests of labor and management may be said to be antagonistic. Yet conflict between them, as in bargaining negotiations or strikes, may only occasionally characterize their relations. Similarly, on the international plane, national states, having opposed interests, may engage in conflict only at certain periods. . . . If the adversary's strength could be measured prior to engaging in conflict, antagonistic interests might be adjusted without such conflict; but where no means for prior measurement exists, only actual struggle may afford the exact knowledge of comparative strength ... . [by which] accommodation may ... be reached [p. 135].

Thus Coser defines conflict behaviorally, i.e., as antagonistic struggle, a social interaction process which sometimes takes place as the result of certain patterns of psychological relationships between the parties ("hostile sentiments or attitudes," "antagonistic interests," “opposed interests").

In the same vein, Williams, Wright, and Kerr distinguish the actual process of conflict from various underlying psychological patterns which they call "hostilities," "tensions," "inconsistencies," "grievances," or the "dissatisfactions and discontents of the parties with each other." In this "actioncentered" conception, one or more of these psychological antagonisms may be present in all instances of social conflict, but the psychological patterns do not by themselves warrant use of the term. According to these writers (among many others) a social rela- 
tionship is not "conflict" unless it involves an actual struggle.

On the other hand, there is considerable support, both in common usage and in the social science literature, for Dahrendorf's broader conception. Kurt Singer (1949b) points to the fate of the term in ordinary language:

Conflict is a Middle English coinage of tolerably well defined meaning in common usage. Its derivation from the Latin confligere, to strike together, to clash, suggests that it first designated an actual encounter with arms. It denotes a fight, a struggle, especially one that is prolonged and intense. From the human sphere and the facts of war it has at an early date been transferred to natural (physical) processes . . . but there is a tendency to shift the centre of gravity of the term to psychic states harbouring opposed ideas, feelings, strivings; and finally to collisions of tendencies and claims that are, or appear to be, incompatible. ... According to the older usage, war would certainly be regarded as a signal form of conflict. After the psychological aspects of conflict have shifted into focus, the sociologist Georg Simmel could ask whether actual struggle is not a form of solving a conflict rather than an instance of it [pp. 145-46].

Both Dahrendorf and Singer thus present "motive-centered" conceptions which shift the emphasis from the struggle itself to the underlying psychological patterns that motivate the struggle. The same is true of definitions of conflict offered by such writers as Levinger (1957), North et al. (1960), Boulding (1962), Aubert (1963), Galtung (1965b), and Stagner (1967), who thereby extend the term to situations that may not involve any overt struggle.

The theoretical significance of this issue lies mainly in the assumption that the specified psychological states do not always lead to conflict behavior. This was the basis for the assertion by Mack and Snyder that such states, though relevant, are not sufficient conditions for the occurrence of conflict. But even if one ignores the presumed causal connections between them, it seems obvious that antagonistic psychological relations are not the same sort of phenomena as antagonistic interactions. In common sense terms, the statement that $A$ and $B$ hate each other is obviously not the same as the statement that $\mathrm{A}$ and $\mathrm{B}$ hit each other; similarly, the fact that A and B have mutually incompatible goals is not equivalent to the fact that they engage in mutual sabotage in pursuit of their respective goals.

Given the distinction between psychological and behavioral aspects of conflict, any choice between an action-centered and a motive-centered definition has important consequences for both theory and research. Theoretically, questions concerning the causes, course, and consequences of conflict have different meanings and must therefore be answered differently depending on whether the "conflict" referred to is a pattern of psychological opposition or an overt struggle. The most obvious cause of conflict behavior is a prior conflict state, but the causes of conflict states may be more difficult to discern. Predictions of how long a particular opposition will persist cannot be made on the same basis as predictions of how long a particular struggle will last, because the total configuration of determinants is different in the two cases. One of the consequences of a conflict state may be the initiation of a conflict process, while one of the consequences of a conflict process may be the resolution or elimination of a conflict state. Various other terms in the theory of conflict, such as "intensity," "severity," "importance," "resolution," "tolerance," "control," “institutionalization," "management," or "termination" of conflict will have quite different meanings depending on whether conflict is conceived as a 
state of affairs or as an interaction process. Methodologically, the two kinds of definitions imply quite different criteria for identifying a particular instance of conflict, since there is no one-to-one correspondence between conflict states and conflict processes, the former sometimes occurring without the latter.

Granting the importance of these differential implications, a choice between the broader and narrower conceptions of conflict on this psychological-behavioral dimension seems to be a choice between two quite different conceptual systems. However, this may be more a question of terminology than of concepts.

Mack and Snyder, Coser, and others who prefer the narrower conception of conflict as a form of interaction seem to do so on grounds that the broader conceptions lead to more confusing formulations. Emphasizing the need for a clear distinction between psychological and behavioral patterns, they argue that in order to achieve such clarity, it is necessary to restrict the term "conflict" to instances of overt struggle. But Bernard (1949) argues for a motive-centered conception on precisely the same grounds, i.e., that the action-centered conceptions lead to more confusing formulations. She argues that in order to achieve a clear distinction between the overt struggle and the underlying issues, it is necessary to recognize that the real conflict is located in the issues:

From time to time, to be sure, conflict is precipitated into clear-cut issues. ... But sometimes actual conflict may exist in latent form for years before there is a formulation of issues or a showdown or crisis. The danger in our confusing the overt conflict-a strike, a fist fight, a riot-with the conflict itself is that in trying to avoid these crises we may forget that the true issue is much more basic than the precipitant which brings on a crisis. It is a mistake to limit our thinking about conflict to the overt phase of showdown or crisis. If we do, then the study of conflict in the community becomes merely a study of the technology of overt conflict-strikes or riots. It should be much more fundamental than that. We must accustom ourselves to thinking of latent conflict as going on day in and day out in varying degrees of intensity, whether the issues are clearly formulated or not [p. 106].

Thus both sides agree on the need for the conceptual distinction, and both imply theories that include propositions about the conditions under which a psychological antagonism will lead to an overt struggle. But they prefer different terminologies: given an action-centered definition of conflict, the underlying psychological patterns are called "hostility" or "antagonistic interests" and the like; given a motive-centered definition, the psychological patterns may be called "latent conflict," while the interaction patterns may be called "overt conflict" (Bernard) or "manifest conflict" (Dahrendorf).

The degree to which the choice is between terminological systems rather than conceptual systems is illustrated in two statements by Wright (1951, 1965) of his framework for analyzing the dynamics of war. The earlier piece presents a rough sequential model in which he distinguishes the following:

1. Inconsistencies in the "sentiments, purposes, claims, or opinions of social entities" (e.g., radical differences of religion, ideology, or institutions); when the parties initiate action based on their respective orientations, these inconsistencies lead to

2. social tension, a "condition" whose magnitude depends on the strength of the parties and on the closeness of contact between them; the magnitude of social tension, in turn, determines the probability of

3. conflict, a "process" of resolving the inconsistencies; if this process does not succeed, and if tension is high enough and 
regulatory arrangements are ineffective, conflict is likely to escalate to the level of

4. open violence, of which war is a special case (1951, pp. 193-97).

This scheme is consistent with the narrow conception of conflict, restricting the term to overt struggle. But in his later presentation, Wright seems to have compromised with the broader usage:

Conflict is a particular relationship between states and may exist at all levels and in various degrees. In the broad sense of the term it may be divided into four stages: (1) awareness of inconsistencies, (2) rising tensions, (3) pressures short of military force to resolve the inconsistencies, and (4) military intervention or war to dictate a solution. The first two periods, in which conflict is latent, may be characterized by an arms race. . . . Conflict in a narrow sense refers to a situation in which the parties are taking action against each other, i.e., to the last two stages of conflict in the broad sense [1965, pp. 434-35].

Here the conceptual system has remained the same, but the terminological system has changed. The issue is simply whether the term "conflict" should apply to only part (manifest conflict only) or to all (latent plus manifest conflict) of a unified dynamic process. Whichever terminology is adopted, a clear conceptual distinction between latent and manifest stages of the process remains, as does the concept of the process as a dynamic whole. Thus, extending the definition of conflict to include purely psychological antagonism may have less substantive impact on the theory than it first seemed to have. Such an extension requires other terminological changes in the theory, but will not affect the substantive propositions so long as they are properly translated.

CONFLICT VS. OTHER FORMS OF STRUGGLE

More significant is the second issue raised by the contrast between broad and narrow conceptions, i.e., the question of which forms of struggle should be subsumed under the heading of social conflict. Mack and Snyder regard conflict as one species of struggle, treating competition, rivalry, and other forms as distinct species. Dahrendorf, on the other hand, treats all of these as forms of conflict, which in this sense becomes the genus to which various species of struggle belong. Unlike the extension to include psychological patterns, this is not merely a shift in the system for labeling different stages of the same process, but rather an extension of the term to include other kinds of processes. It thus has considerable substantive impact on the theory, because it automatically changes the relevant empirical base, and with it the set of empirically valid propositions which can be stated about conflict phenomena.

A debate between Mack (1965) and Dahrendorf (1959) over the inclusion of competition illustrates the nature of the substantive questions which are raised. In stating his broader conception, Dahrendorf argued as follows:

Despite terminological traditions, I can see no reason why a conceptual distinction between competition and conflict should be necessary or, indeed, desirable. (At least, no such reason has been put forward.) Like competition, conflict involves a striving for scarce resources. From the point of view of linguistic usage, it is perfectly proper to say that conflicting interest groups compete for power. As far as the "established rules" of competition are concerned, they emphasize but one type of conflict, namely, regulated conflict [1959, p. 209].

Mack replied to this by giving some reasons why the distinction is desirable:

Another problem in pushing forward our understanding of conflict and in systematizing what we know about it stems from our loose use of the word. Surely we could increase the efficiency of our research designs and our theory-building were we to distinguish between competition (the act of striving for some object 
that is sought by others at the same time, a contention of two or more persons or groups for the same goal) and conflict (opposition or antagonistic struggle, the aim of which is the annihilation, defeat, or subjugation of the other person or group [p. 391].

Citing the Latin origins of the two words, he went on to explain why such a distinction is "conceptually efficient":

Competition is from com (together) and petere (to seek). Conflict derives from com (together) plus fligere (to strike). The distinction between the quest and the blow, to strive or to strike, seems precisely the pertinent one for clarity and efficiency in social science. Of course they are both processes of opposition, and of course there will be cases of overlap and confusion. But I disagree with Dahrendorf's contention that a conceptual distinction between conflict and competition is neither necessary nor desirable. Competition involves striving for scarce objects according to established rules which limit what the competitors can do to each other in the course of striving. The chief objective is the scarce object, not the injury or destruction of the opponent. When a miler decides that he is not going to get his second wind and cannot possibly beat the runner beside him to the tape, and he therefore pokes his foot between the other fellow's legs, more has occurred than a sociologist's joy at his ability to distinguish with great precision between competition and conflict. The nature of the interaction has changed. . . . We can use a distinction between competition and conflict to sharpen our focus upon the point at which men abandon institutionalized norms. Equally important, such conceptual efficiency might help us to understand the process whereby conflict becomes institutionalized, the parties come to accept rules to govern the limits of the opposition, and the conflict shades into competition [pp. 391-92; italics added].

The main point of Mack's argument is the thesis that these two kinds of processes must be theoretically separated because the underlying psychological patterns, and consequently the behavioral patterns, are different in the two cases. It contrasts sharply with Dahrendorf's main argument for his broader definition of conflict:

It is important to realize that this conceptual decision is not merely of terminological significance. It implies, and is supposed to imply, that civil war and parliamentary debate, strike and negotiation are essentially motivated by the same type of social relationship and are therefore but different manifestations of an identical force [1959, p. 135; italics added].

This says that despite the obvious differences in behavioral patterns, the underlying psychological patterns are similar, and therefore the two kinds of processes should be theoretically united.

There is actually more conceptual agreement here than was first apparent. Both authors recognize the existence of two species of antagonistic struggle, distinguished by the fact that one is regulated and the other is unregulated. To this extent, Dahrendorf does see the necessity for a conceptual distinction; what he does not see is the necessity for accepting Mack's labels ("competition" and "conflict"). Furthermore, both authors have a concept of the genus to which the two species belong; but Mack refers to this as "opposition," while Dahrendorf calls it "conflict." So far, this debate over the definition of conflict is merely a terminological quarrel about whether to use the term to name one species or to name the genus.

Nevertheless, there remains a crucial conceptual difference. Dahrendorf postulates an underlying psychological similarity between regulated and unregulated struggles (both involve incompatible goals), which justifies the inclusion of both under a single heading. Mack, on the other hand, though not denying that similarity, postulates an additional psychological difference, which provides equal justification for keeping the two kinds of struggles under separate headings. This is not inconsistent with Dahren- 
dorf's postulate, since there is no reason why similar patterns of goal-orientations must be accompanied by similar patterns of meansorientations. But it does seem to give Mack a more powerful argument, because he has indicated a psychological difference which may help account for the observed behavioral difference, while Dahrendorf's postulate of psychological similarity could only account for behavioral similarities between the two forms of struggle.

Even this theoretical difference would disappear if Dahrendorf had explicitly acknowledged the psychological dissimilarity between the two. However, it would not resolve the original question of whether we should restrict the term "conflict" (and thereby the theory of conflict) to unregulated struggles or broaden it to include regulated struggles as well (thereby changing the theory into what Mack might call a theory of "opposition"). The implication of Mack's discussion is that a theory of conflict would focus on unregulated struggles, dealing with regulated struggles only insofar as they are causally related to unregulated struggles. The same would presumably apply to any other form of struggle (e.g., rivalry) which Mack might distinguish from conflict. Conversely, Dahrendorf implies that all forms of antagonistic struggle are of equal concern for a theory of conflict, even in cases which do not involve causal relations between two different forms. Therefore, the choice between these narrow and broad conceptions is not merely terminological, but is theoretically significant in that the latter implies a larger empirical domain and additional substantive content for the theory.

\section{COMPLEXITY OF THE CHOICE}

It is important to note that the problem is not simply a matter of choosing between Mack and Snyder's narrow definition of social conflict and Dahrendorf's broad definition. If it is true that the narrow conception does not dominate the field, it is also true that the field is not strictly polarized into two contradictory conceptual traditions. Several independent conceptual decisions are involved in constructing a definition of conflict, and not all theorists who agree on one of these decisions will necessarily agree on the others.

Mack and Snyder's action-centered definition restricts the term "conflict" to one species of overt struggle. Dahrendorf's motive-centered definition broadens it to include latent antagonisms and also to include other forms of struggle. But it is not necessary to reject or accept both of these extensions, since one does not logically imply the other. Thus, it is possible for a motive-centered definition to restrict the term "conflict" to one species of antagonistic relationship, and for an action-centered definition to extend it to include all species of struggle.

Some writers who treat conflict as one species of struggle do not impose the same restrictions as do Mack and Snyder against using the term for latent antagonisms. Thus Wright (1951) sharply distinguishes conflict from competition and rivalry, but (as shown above) his later scheme (1965) admits the possibility of using conflict in a broad sense to include both latent and manifest stages of the process. Williams (1947) goes even further than this. As noted earlier, he usually speaks of the underlying psychological patterns as "hostility" and "tension"; but he also introduces, among other motivational bases of intergroup conflict, the concepts of "conflict of interests," "conflict of values" (cultural conflict), and "conflict of personality types." Williams gives these the status of defined terms in the theory, thus explicitly deviating 
from a strictly action-centered conception of conflict. Still more explicit is Bernard (1949, 1957a, 1960), who develops separate theories of conflict and competition, but gives them both motive-centered definitions. She refers to the psychological aspects of conflict as "conflict situations" (latent conflict, conflict phenomena, value conflicts, issues; conflict of interests, of ideas, of wishes, etc.), and to the behavioral aspects as "overt conflict" or "conflict behavior." Other writers who seem to follow Bernard's conception distinguish conflict situations from overt conflicts (Koch et al., 1960; North et al., 1960), latent conflicts from manifest conflicts (DeKadt, 1965), or "conflict topics" from "conflict cycles" (Goldman, 1966). Finally, there are some writers who go so far as to restrict the term "conflict" to the psychological patterns, referring to the consequent behaviors as "struggle," "active opposition," or "antagonistic interaction." One example is Shepard (1964), for whom overt struggle consists of various methods of handling, managing, resolving, or responding to "situations of competition and conflict."

Conversely, some writers who subsume forms of struggle excluded by Mack and Snyder nevertheless retain an action-centered definition of conflict. For example, MacIver (1937, p. 51) defines conflict as "all activity in which men contend against one another for any objective," and includes litigation, polemics, duels, revolutions, wars, competition, bargaining, gambling, and other forms of struggle. Occasionally he refers to the underlying psychological patterns as "conflict situations," "latent conflict," or "conflict of interests"; but his explicitly defined terms for the motivational bases of struggle are "inharmonious like interests" and "unlike attitudes" (pp. 53-54). He also uses a variety of other synonyms for the psychological patterns-"competing desires," "discordant like interests," "cleavage of interests," "antagonism," "divergent interests," "hostile attitudes," "emotional hostility," "tensions," and "strains." MacIver's terminology is very close to that of Simmel (1955), who occasionally refers to the underlying psychological patterns as latent conflict, relations of conflict, or conflicting interests; but most often uses terms such as "inner divergence," "antagonism," "mutual repulsion," "antipathy," "mutual hostility," and "disharmony." Van Doorn (1966) follows the same general terminology. Beals and Siegel (1966) define conflict as a process in which "two parties belonging to the same organization exchange behaviors that symbolize opposition" (p. 18), and refer to the underlying psychological patterns as "opposition," "tension," or "strain." This is clearly an action-centered conception, but it is broader than Mack and Snyder's because it subsumes competition. Nicholson (1967) obviously includes several forms of struggle in his classification of conflict ("games," "threat conflicts," "bargaining conflicts"); but his also remains an action-centered conception because he refers to the psychological bases of the conflict only as "differing," "divergent," or "opposed" interests.

This demonstrates the logical independence of the two decisions, i.e., the decision to subsume latent antagonisms and the decision to subsume competition and other forms of struggle as instances of conflict. It also indicates that definitions which do not clearly specify the author's intent on both dimensions necessarily remain ambiguous. For example, Berelson and Steiner (1964) define social conflict as "the pursuit of incompatible, or at least seemingly incompatible, goals, such that gains to one side come about at the expense of the other" 
(p. 588). This is clearly action-centered, but it gives no direct clue as to which forms of struggle are to be included. The same is true of Loomis' (1967) definition of conflict as "social action in which an actor or actors attempt, in the face of human opposition, to achieve one or more goals" (p. 875). Motive-centered definitions are no less ambiguous: thus Rex (1961), Thurlings (1965), and Johnson (1966) seem to adopt Dahrendorf's conception, but they are not explicit about subsuming all forms of struggle, and the content of their theories suggests that they might exclude some phenomena which Dahrendorf would include.

Such ambiguities are all the more obvious in light of the fact that there are various forms of struggle which might be included, and that different authors subsume or exclude different sets of these. Most writers who treat conflict as one species of struggle agree with Mack and Snyder that competition should be excluded. Some also agree to exclude rivalry, treating it either as a form of competition (Von Wiese and Becker, 1932) or as a third species (Wright, 1951). But some of them treat rivalry as a form of conflict (Park and Burgess, 1924), and many fail to exclude it explicitly. On the other hand, some of these writers distinguish additional species of struggle which are not explicitly excluded by Mack and Snyder, such as controversy (Ross, 1930), contravention (Von Wiese and Becker, 1932), opposition (Von Wiese, 1941; Gross, 1966), contest (Coser, 1956), or antagonism (Gross, 1966). Still other writers treat conflict as one species of struggle, but do not explicitly exclude competition. Thus Holsti (1966) distinguishes conflict from two other forms which he calls disputes and tensions. According to Beals and Siegel (1966), conflict subsumes competition but is distinguished from fighting and warfare (which Mack and Snyder would probably include). The general picture which emerges is that various conceptions of social conflict subsume overlapping but nonidentical sets of phenomena. The choice is thus not merely between a broad and a narrow conception, but rather between several alternative conceptions which vary in breadth on more than one dimension and in various degrees.

\section{Shifting Conceptual Boundaries: Conflict vs. Competition}

The complexity of the choice is actually much greater than indicated above. Every conception of conflict is part of a larger conceptual system which contains terms referring to various psychological and behavioral aspects of conflict and to various types of situations and processes. Any conceptual decision about the meaning of conflict is therefore imbedded in a network of conceptual decisions about the meanings of other terms, and of terminological decisions about what labels to assign to other concepts and phenomena. These other terms may also vary in meaning, so that what is included in or excluded from the category "conflict" cannot be adequately stated without also examining the definitions of these other terms. Since "competition" is the most frequently excluded category, an analysis of the shifting boundaries between conflict and competition will serve to illustrate the many dimensions of conceptual choice that are actually involved in defining social conflict.

\section{BROAD CONCEPTIONS OF COMPETITION}

The debate between Mack and Dahrendorf focused on the question of whether or not competition should be treated as a special case of conflict. Mack argued against this on grounds that competition is, both 
psychologically and behaviorally, a separate species of struggle. This entails not only a narrow conception of conflict but also a narrow conception of competition. But there is no more unanimity on the latter than there is on the former. As indicated earlier (p. 430 above), there are many writers who adopt broad conceptions of competition. Sometimes competition subsumes conflict as a special case, and sometimes the two are synonymous.

The first of these possibilities appears in Lasswell's (1931) definition of conflict as a form of competition:

Social conflict results from the conscious pursuit of exclusive values. In the widest sense of the word conflict is conscious competition, and competitors become self-conscious rivals, opponents or enemies [p. 194].

Boulding (1957) presents a more elaborate statement of the same relationship:

Generally, we may wish to reserve the term "competition" for the wide concept which includes interactions among unorganized aggregates (such as biological populations) and to use the word "conflict" for the narrower concept in which the conflicting parties are individuals or organizations, possessing a certain core of unity of behavior and in which each organization is in some sense "aware" of the other and makes this awareness an essential part of its behavior pattern [p. 122].

Both of these statements are consistent with some of the formulations of Park and Burgess (1924), who state that "competition takes the form of conflict or rivalry only when it becomes conscious, when competitors identify one another as rivals or enemies" (p. 506) and refer to conflict as "conscious competition" (pp. 576, 579ff). Thus, although many writers have derived from Park and Burgess the distinction between competition and conflict as two major species of struggle (Coser, 1964; Friedsam, 1964), the same source supports the view that competition is the genus of which conflict is but one species. This relationship is preserved when Boulding (1962) shifts from the action-centered definitions cited above to a motive-centered definition of conflict:

Competition in its broadest sense exists when any potential positions of two behavior units are mutually incompatible. This is a broader concept than conflict, as we shall see, in the sense that, whereas all cases of conflict involve competition in the above sense, not all cases of competition involve conflict. . . . Conflict may be defined as a situation of competition in which the parties are aware of the incompatibility of potential future positions and in which each party wishes to occupy a position that is incompatible with the wishes of the other. . . One can ... postulate a condition of competition among animals or men that would not involve conflict, because there would be no awareness of the competitors. . . Similarly, ... even where people are aware of potential conflict, there may be no actual conflict if there is no desire on the part of one party to occupy a region of its behavior space from which it is excluded by the other [pp. 4-5].

The treatment of conflict and competition as synonyms is clearly suggested by the equivalence of some definitions of the two terms. For example, Doob (1952) and Deutsch (1953) offer motive-centered definitions of competition which are conceptually indistinguishable from several motivecentered definitions of conflict. Doob defines competition from a psychological viewpoint as a situation involving "a goal which, being scarce, cannot be shared by or appears unsharable to the individuals concerned" (1952, p. 210). Deutsch's definition of "competitive social situations" is stated in more abstract Lewinian terms:

The goal regions for each of the individuals or subunits in the situation are defined so that, if a goal region is entered by any individual or subunit . . . the other individuals or subunits will, to some degree, be unable to reach their respective goals in the social situation under consideration. . . . The phrase contriently inter- 
dependent goals will be used to identify any such situation ... [p. 320].

Doob's conception of competition is virtually the same as Stagner's definition of conflict, "a situation in which two or more human beings desire goals which they perceive as being attainable by one or the other but not both" (1967, p. 136). Deutsch's conception of competition is similar to the definition of conflict offered by North, Koch, and Zinnes (1960):

A conflict develops within or between organizations whenever two or more policy conditions [organizational goals or purposes with a time specification] are incompatible [i.e., cannot obtain simultaneously]. . . A conflict situation consists of all policy conditions which are mutually incompatible at a given time (regardless of whether they issue from the same organization, different organizations, or a combination of both) [p. 356].

It also closely resembles Boulding's definition of conflict quoted above, Galtung's definition of conflict as a property of an "action system" (i.e., a system of actors) in which the system has "two or more incompatible goal-states" (1965b, p. 348), and Dahrendorf's definition of "relations of social conflict" as "all relations between sets of individuals that involve an incompatible difference of objective" (1959, p. 135). Many more examples of such equivalence could be cited.

Despite these similarities, the actual use by a single author of "conflict" and "competition" as synonyms is relatively rare. It might be appropriate to treat Dahrendorf's system as one example, since he explicitly argues against making a distinction between them. On the other hand, it would be more accurate to say that he drops the term "competition" altogether, at least in the scheme discussed here. There are some authors who refer to "competing interests" and "conflicting interests" interchangeably, but these are usually only casual references. The most common practice among writers who equate conflict and competition conceptually is to use only one of the terms in formulating theories or generalizations.

\section{COMPETTTION AS REGULATED STRUGGLE}

Even among writers who define competition more narrowly as one species of struggle, there is no unanimous acceptance of the conception presented by Mack and Snyder. In his debate with Dahrendorf, Mack (1965) emphasized the criterion of regulation as the key to distinguishing conflict from competition. The latter is regulated (i.e., involves established rules or institutionalized norms which limit what the competitors can do to each other in the course of striving to reach their respective goals), but conflict is unregulated (i.e., involves the violation of the rules). This same criterion is used in the UNESCO Dictionary of the Social Sciences (Coser, 1964; Friedsam, 1964), as well as in the earlier Dictionary of Social Science compiled by Zadrozny (1959). It also occurs in the Encyclopedia of the Social Sciences (1931; articles by Hamilton and Lasswell), and in works by other writers such as Williams (1947) and Davis (1949). But there are many other writers who do not base the distinction on regulation, some explicitly stating that both conflict and competition can be either regulated or unregulated (e.g., Park and Burgess, 1924; Ross, 1930; Von Wiese and Becker, 1932; Lundberg, 1939; Bernard, 1949; Wright, 1951; Kerr, 1954; Angell, 1965; Timasheff, 1965).

Among writers who define conflict more broadly, the parallel distinction is between "competition" and other forms of conflict. In most of these schemes, competition is not distinguished by the criterion of regulation (e.g., Carver, 1915; Simmel, 1955; Weber, 1947; MacIver, 1937; Lawner, 
1956; Levinger, 1957; Dahrendorf, 1961; Aubert, 1963; Beals and Siegel, 1966). Some of these authors also state explicitly that both competition and other forms of conflict may be either regulated or unregulated. It thus appears that the great majority of theorists do not agree with Mack's contrast between competition as regulated struggle and conflict (= "other forms of conflict" in some schemes) as unregulated struggle.

Even among those writers who do define competition as regulated struggle, there is considerable diversity in specifying the nature of the regulation. Some merely state that there are rules:

(a) Competition is rivalry subdued into organization by rules of the game [Hamilton, 1931, p. 142; italics added].

(b) Competition [is] the more or less impersonal and continuous social process by which two or more groups of people consciously and deliberately strive to achieve some limited goal (or portion thereof), while observing certain rules of procedure [Zadrozny, 1959, p. 59; italics added].

But these definitions say nothing about the content of the rules. Others are slightly more specific:

(c) Competition simply aims to outdo the competitor in achieving some mutually desired goal. ... It implies that there are rules of the game to which the competitors must conform and that behind these rules, justifying and maintaining them, is a common set of values superior to the competitive interest. It also implies an absence of coercion. . . . The rules of competition limit the means that may be used [Davis, 1949, p. 162; italics added].

(d) Competition is that form of interaction which involves a struggle for goals which are scarce or are believed to be scarce; the interaction is normatively regulated, may be direct or indirect, personal or impersonal, and tends to exclude the use of force or violence [Friedsam, 1964, p. 118; italics added].

These at least indicate the kinds of behavior which the rules prohibit. But they specify a different aspect of the rules than do Mack and Snyder, who state that the rules strictly limit what the competitors can do to each other $(1957$, p. 217). Both of these aspects (the content and the target of the behavior) may be combined, however:

(e) [Competition is] a continuing struggle for scarce, distributive values in which the focus is upon reaching a goal rather than removing competitors, and which is regulated by rules prohibiting forceful removal of competitors. It may be completely impersonal and outside personal awareness [Williams, 1947, p. 47; italics added].

These various definitions indicate that even when regulation is used as a criterion, the boundary line between competition and conflict is drawn in different places by different authors. Actually, among the six schemes cited here, only Davis and Mack and Snyder appear to define conflict as unregulated:

When competition breaks through the rules it transforms itself into conflict [Davis, 1949, p. 162].

A football game played normally according to the rules is competition until one or more players begin to assault one another in a manner forbidden by the rules; then it becomes a conflict [Mack and Snyder, 1957, p. 217].

All of the others merely imply, by contrast with their definitions of competition, that all conflicts are unregulated. But, by not making this explicit, they leave open the possibility that some conflicts may be regulated. Even Mack and Snyder contradict their own notion of conflict as unregulated:

Conflict relations do not represent a breakdown in regulated conduct but rather a shift in the governing norms and expectations. ... The conflict process is subject to its own rules and limits [1957, p. 219].

This suggests that, in their view, conflict and competition are distinguished not by the following or abandoning of norms, but rather by differences in the content of the 
norms which apply. At the very least, it is obvious that if both conflict and competition may be regulated, the criterion of regulation does not provide a clear basis for defining and distinguishing between them.

One writer who did base the distinction partly on differences in the content of the governing norms was Ross (1930):

The chief types of opposition are competition and conflict. The contrast between them is that between a race and a fight. In the former you may do nothing to thwart the efforts of your opponent; in the latter you may block his efforts, even cripple or disable him [p. 156].

Competition resembles a race rather than a fight, for in a fight it is quite proper to "knock out" your opponent; but tripping your rival in a race is regarded as bad sportsmanship [p. 166].

In other words, we resent a success won by some other prowess than the one called for. We are disgusted by the fight that becomes a "foot-race" and by the foot-race that becomes a fight; by the slugging match that becomes a "joint debate" and the joint debate that becomes a slugging match [p. 171].

Here the crucial difference is not the presence or absence of rules, but rather differences in the modes of behavior that are prescribed, permitted, or proscribed by the rules. But this still fails to provide a clear basis for the distinction. For example, it is not clear how to treat norm violations. Does violation of the rules of competition convert the process into an unregulated competition or into a conflict? Similarly, does violation of the rules of conflict convert the process into an unregulated conflict or into a competition? More important, how does one distinguish between conflict and competition when they are "unregulated" due to the absence rather than the violation of rules? The necessity for dealing with this last situation is clear from Ross' discussion of the problem of regulating competition:

In the absence of binding rules or accepted standards of fairness competition assumes ex- travagant or vicious forms. . . . Courts and administrative boards have outlawed a great number of practices as "unfair." ... In old societies ... the recognized forms of competition are hemmed in by standards, so that in most arenas honorable young men may compete without losing their self-respect. The rearing of a ring fence about every competition indicating just what is and what is not permitted is a moral achievement which takes time. . . . No young society has such restraints any more than it has mossy manses and ivy-clad church towers [pp. 168-72].

But if this is the case, then competition must be identifiable as such on grounds other than the content of the rules which govern it. The same is true for conflict. In other words, the recognition of unregulated forms of both competition and conflict precludes the possibility of distinguishing between them according to either the presence or the content of rules governing the interaction.

\section{COMPETITION AS INDIRECT STRUGGLE}

Consequently, other defining characteristics have been given a more central place by most writers, including those who rely in part on the criterion of regulation. The most obvious alternative to specifying the modes of behavior which the rules permit or prohibit is simply to specify the modes of behavior which may actually occur in any instance of competition or of conflict, regardless of whether these behaviors conform to the rules, deviate from the rules, or take place in an anomic or normless situation. It is in fact such behavioral differences which Ross was trying to emphasize when he stated that, in competition (e.g., races), "You may do nothing to thwart the efforts of your opponent," while in conflict (e.g., fights), "You may block his efforts, even cripple or disable him." Expanding upon this, Ross stated further:

Hence competition, unlike conflict, stimulates but does not destroy. Nothing excites anger 
like being repeatedly thwarted, so the emotion begotten by conflict is anger; but the beaten competitor is stirred to envy or jealousy rather than to anger [p. 156].

There is in conflict, as distinguished from wholesome competition, an element which is altogether bad. This may be called Antagonistic Effort, i.e., equal efforts expended in opposite directions, so that A is neutralized by B and B is neutralized by A. . . . So long as the antagonistic efforts are in balance nothing is settled. All exertions which are promptly met and neutralized by counter-exertions are wasted, for they decide nothing. It is only the margin of superiority that counts. Hence the peculiar ruinousness of opposition which assumes this form [p. 162].

Mack's (1965) reference to the Latin origins of "competition" and "conflict" was an attempt to convey this same distinction, which he characterized as that between the "quest" and the "blow," or between "to strive" and "to strike." Gross (1966) made this the key to distinguishing competition from conflict and other dissociative processes:

"Conflict" is the "escalation" of antagonism to its most intensive degree, involving a mustering of forces and preparation for, or engagement in, a direct clash of adversaries [p. 25; italics added].

Each competitor tries to achieve its goal without direct use of the strength of its competitor [sic]. Open obstruction or interference with the activities of the competitor would, in reality, change the competition to antagonism. ... Competition ... does not impair the strength of the adversary; in a sense it stimulates it [p. 38].

Wright (1951) put it somewhat differently:

Conflict, defined as opposition among social entities directed against one another [italics added], is distinguished from competition, defined as opposition among social entities independently striving [italics added] for something of which the supply is inadequate to satisfy all [p. 197].

What these various formulations have in common is a conceptual distinction between two behavioral patterns: "competition" is characterized by parallel striving, while "conflict" is characterized by mutual interference.

The emphasis on this criterion goes back at least to Simmel, who states it this way:

The foremost sociological characteristic of competition is the fact that conflict in it is indirect. In so far as one gets rid of an adversary or damages him directly, one does not compete with him. In general, linguistic usage reserves the term only for conflicts which consist in parallel efforts by both parties concerning the same prize. ... The other types of conflict ... make for the mutual annihilation of the combatants, and to society as a whole leave only the difference obtained by subtracting the weaker from the stronger force [1955, pp. 57-60; italics added].

MacIver (1937) made this the principal basis for classifying conflicts:

Taking the term "social conflict" to include all activity in which men contend against one another for any objective, we may distinguish direct and indirect conflict as its two fundamental types. Direct conflict occurs where individuals or groups thwart or impede or restrain or injure or destroy one another in the effort to obtain some goal. . . . Indirect conflict occurs where individuals or groups do not actually impede the efforts of one another but nevertheless seek to attain their ends in ways which obstruct the attainment of the same ends by others. Competition in all its varieties comes within this class. Competitors do not, as such, interfere with the activity, but only with the success of one another [p. 51].

This basis for distinguishing "competition" from other forms of struggle is thus shared by some writers whose conception of conflict subsumes competition, as well as by some for whom conflict excludes competition.

But there is by no means universal agreement that the contrast between "direct" and "indirect" interaction is or should be the key to the distinction between competitive and other forms of struggle. Some writers explicitly deny it. For example, Timasheff 
(1965) includes some forms of direct struggle under the heading of "unfair competition." Friedsam (1960) states that competition may be either direct or indirect. Bernard (1949, p. 47) asserts that while some forms of competition may be less direct than some forms of conflict, this is simply an incidental characteristic that does not apply to all cases. Some writers implicitly deny the relevance of the direct vs. indirect distinction, since they focus not on interaction but rather on other characteristics of the situation (e.g., Levinger, 1957; Dahrendorf, 1961; Aubert, 1963; Beals and Siegel, 1966).

Still other writers focus on interaction patterns, but their distinctions are ambiguously related to the directness or indirectness of the struggle. For example, Park and Burgess (1924, p. 574) define competition as an unconscious, impersonal, continuous struggle in which the parties are not necessarily in contact and communication; conflict, on the other hand, is a conscious, personal, intermittent contest in which contact is an indispensable condition. At first glance, it appears that this is just a more elaborate way of stating the indirect-direct distinction. Impersonal struggle with no (social) contact or communication between parties who are not aware of each other can be construed as an instance of "indirect interaction," "parallel efforts," etc. But direct struggle can also occur without communication, as suggested by Lundberg's (1939) assertion that the essence of conflict situations is abstinence from communication, which does not, however, preclude the (physical) contact required for mutual extermination. Furthermore, the presence of (social) contact and communication between the parties does not necessarily imply that the struggle will be direct in the sense intended by Simmel, Ross, MacIver, and others. There is nothing inherent in social contact and communication that would lead parties with opposed goals to directly interfere with each other's goal-seeking activities. Therefore, the behavioral differences emphasized by Park and Burgess are not identical with the contrast between direct and indirect interaction.

The same is true of behavioral distinctions presented by other authors. For example, Weber (1947) divides all conflicts, according to the "normally used means" of struggle in each type, into violent physical conflict and peaceful conflict, subsuming competition under the latter category. But though Weber may have intended this to mean that all competition is indirect, it does not clearly do so since some peaceful struggles may be direct. Conversely, writers who state that (noncompetitive) conflict may involve the use of either violent or nonviolent means (e.g., Lasswell, 1931; Lawner, 1956; Zadrozny, 1959; Angell, 1965) do not clearly imply that all such conflicts are direct, since some nonviolent means are indirect. Timasheff (1965), on the other hand, makes it quite explicit that both violent and nonviolent conflicts are to be construed as involving direct interaction. But this merely reinforces the notion that violent vs. nonviolent is a different dimension from direct vs. indirect.

Still another behavioral basis for distinguishing competition from conflict was presented by Von Wiese and Becker (1932):

The three principal processes of dissociation .... are distinguished from each other by a gradual increase of definitely antagonistic activity. Competition is the most mixed of the three; it contains so many elements of association or of symbiotic interaction that in most cases only a slight predominance of dissociation can be demonstrated. Contravention (a more precise term for "opposition"), however, manifests well-marked tendencies toward enmity 
and antagonism, although these may remain partially and wholly latent, and are usually disguised. . . . In strong contrast to competition and contravention, conflict is the definite, overt manifestation of antagonism; some of the forms in which it appears are combat, violence, accusation, and similar inimical actions having as their common feature the effort to do harm to the person or plurality pattern opposed. . . Let it be emphasized, however, that competition, contravention, and conflict cannot be distinguished from each other by the degree of externally perceivable injury inflicted, for intense competition or underhanded contravention may do more damage than transitory conflict [pp. 246-47].

Here it is not the specific means of struggle, nor its directness, nor its violence, nor its intensity, nor the degree of communication involved, that makes the difference. Instead, it is the degree to which the struggle is or is not accompanied by elements of nonantagonistic interaction.

Thus, although more writers distinguish competition from (other forms of) conflict on grounds that it is "indirect" than do so on grounds that it is "regulated," there is no general agreement on either of these criteria, nor indeed on any behavioral criterion for the distinction. This is due in part to the fact that many authors with motive-centered definitions of these terms concentrate almost exclusively on psychological elements in their definitions. However, since most writers with action-centered definitions conceive of the action as purposive, they usually make some reference to psychological elements. This raises the possibility that there is greater agreement on psychological criteria than on behavioral criteria for the distinction.

\section{COMPETITION AS OBJECT-}

CENTERED STHUGGLE

A number of psychological differences have already been mentioned in some of the definitions cited above. For example,
Park and Burgess (1924) referred to competition as unconscious, impersonal struggle, and to conflict as conscious, personal struggle. Several other writers have agreed that (noncompetitive) conflict is always conscious (e.g., Ross, 1930; Lasswell, 1931; Von Wiese and Becker, 1932; Williams, 1947; Wright, 1951; Boulding, 1957; Mack and Snyder, 1957; Zadrozny, 1959; Timasheff, 1965), but many others merely imply it, and there are a few dissenters (e.g., Bernard, 1957a; Dahrendorf, 1961) who include unconscious forms of conflict. Furthermore, most writers discuss forms of competition which are conscious, and many explicitly state that competition may be either conscious or unconscious (e.g., Cooley, 1930; Williams, 1947; Timasheff, 1965 ) or else that competition is always conscious (Zadrozny, 1959). Therefore, the criterion of consciousness does not, by itself, provide an unequivocal or agreed-upon basis for the distinction. The same is true of the personal-impersonal dimension. Some writers do treat competition as impersonal, as in Zadrozny's statement that it is "more or less impersonal," or in Angell's (1965, p. 112) restriction of the term to situations in which there are so many parties that none feels that any other is its opponent. However, the great majority of writers, from Simmel, Ross, and Cooley to Bernard, Friedsam, and Timasheff, assume that competition may be either personal or impersonal. Since many writers also make the same assumption about conflict, there is obviously very little acceptance of the personalimpersonal criterion as a basis for distinguishing competition from (other forms of) conflict.

A more widely accepted basis for the distinction emphasizes the nature of the parties' aims or objectives. In his previously cited reply to Dahrendorf, Mack (1965) 
stated that competition involves striving for some goal object that is sought by others at the same time, and that the chief objective is the scarce object, not the injury or destruction of the opponent (a goal presumably characteristic of conflict). Angell offers an equivalent distinction:

Although conflict and competition have in common the fact of struggle, they differ in the main objective of struggle-for conflict, it is defeat of the opponent; for competition, it is to appropriate a scarce resource [1965, p. 113; italics added].

Both of these can be characterized as distinctions between object-centered and opponent-centered struggles. The objectcentered nature of competition is emphasized by several other writers. For example, Ross states that

Competition implies the seeking of the favor of certain individuals or bodies with reference to a single desirable object [italics added] by two or more persons. . . . Unlike emulation, the aim of competition is not simply to win, but to win something in itself desirable [1930, p. 166].

The same idea is contained in various phrases like "the focus is upon reaching a goal rather than removing competitors" (Williams, 1947, p. 43), or "attention is focused chiefly on reward rather than on the competitor" (Young, 1949, p. 64). The contrasting conception of conflict as opponent-centered is conveyed by definitions which assert that in conflict "the aims of the opponents are to neutralize, injure, or eliminate their rivals" (Williams, 1947; Coser, 1956,1964 ), "each deliberately seeks to destroy, subdue, or thwart the other" (Zadrozny, 1959), or "the aim . . . is the annihilation, defeat, or subjugation of the other person or group" (Mack, 1965).

However, these formulations of the "aims," "chief objectives," "main objectives," etc., seem to imply that the motivational basis of competition is desire for some object, while the basis of conflict is the desire to interfere with the opponent. But this implication is not generally accepted, since many authors assume that the desire to obtain some object is a frequent basis for conflict, so that interference with the opponent is not the primary aim, but rather the primary means of attaining the goal. Timasheff (1965) is quite clear on this point. In defining his continuum from "fair competition" to "violent conflict," he describes the shift from object-centered to opponent-centered struggle as follows:

Several traits characterize [fair] competition. The goals are incompatible, i.e., not every actor seeking the goal can achieve it, although all have a hope. And each participant seeks the goal without directly interfering with the similar efforts of the other. . . . By contrast, modalities of competition more toward the center of the continuum involve something of "unfair" competition. While the main effort of each competitor is still expended toward reaching the goal, part of it is also directed toward immediately impeding the other competitor from achieving. ... In extreme, violent conflict, besides the use of actual physical forceand because of the employment of this forcethere is a temporary relegation of the original goal to a secondary position and substitution of the force itself in its place. The elimination or substantial weakening of the opponent, the breaking of his resistance, becomes the immediate goal. Obviously, since this is temporary, the attainment of the intervening goal is sought as a means for achieving the original goal. It should also be clear that in violent conflict the goal substitution is much more complete than in other forms of conflict [1965, pp. 61-63; italics added].

The conception of (noncompetitive) conflict as basically object-centered is also conveyed by Williams' (1947) statement that conflict results from the conscious pursuit of exclusive values, and that it is merely the immediate aim of the opponents to neutralize, injure, or eliminate their rivals. 
In fact, Coser's definition of conflict is only a slight reformulation of Williams' definition, in which Coser drops the term "immediate," but retains the notion of objectcenteredness by stating that conflict is a struggle over values and claims to scarce status, power, and resources. Even Mack and Snyder (1957) emphasize object-centeredness in their statement that all conflicts involve "mutually exclusive and/or mutually incompatible values and opposed values," arising from "position scarcity" and "resource scarcity" (p. 218). The same is true of most writers who distinguish conflict and competition as separate species of struggle, ranging from Lasswell (1931), who begins with the assertion that "social conflict results from the conscious pursuit of exclusive values" (p. 194), to Gross (1966), who characterizes international conflict as follows:

The goals of government A conflict with the goals and interests of government $B$. In consequence, government $A$ acts to interfere with the policies and goals of government $\mathrm{B}$. By its actions, government $\mathrm{A}$ blocks access to goal $\mathbf{B}$, and the actions of government $B$ are thus frustrated [pp. 30-31].

Similarly, most broader conceptions of conflict (from Carver, 1915, to Stagner, 1967) which include conflicting interests or incompatible goals among the defining elements, assert that object-centered motivation is primary in all conflicts.

There are exceptions to this, since a number of writers do indeed distinguish forms of (noncompetitive) conflicts which are basically opponent-centered. This is true of types of conflict in which "an initial hostility, rather than the attainment of a prize, motivates the fight" (Simmel, 1955, p. 60); of cases in which the predominant motivation is "fundamental and conditioned" (Sorokin, 1947, pp. 96-97), "unrealistic"
(Williams, 1947, pp. 40-41), or "nonrealistic" (Coser, 1956, pp. 49-50); and of such types as "interaction conflict" (Boulding, 1957, p. 132), "fights" and "debates" (Rapoport, 1960), "dichotomous conflicts" (Van Doorn, 1966) and "threat conflicts" (Nicholson, 1967). Nevertheless, all of these authors also deal with other types of conflict which are mainly object-centered.

Conversely, opponent-centered motivation is by no means excluded from all conceptions of competition. This is obvious in the above quotation from Timasheff. It also enters into Simmel's conception of competition:

In many other kinds of conflict, victory over the adversary not only automatically secures, but itself is, the prize of victory. In competition, instead, there are two other combinations. (1) Where victory over the competitor is the chronologically first necessity, it itself means nothing. The goal of the whole action is attained only with the availability of a value which does not depend on that competitive fight at all. . . It is the specific coloration of the competitive struggle that its outcome itself does not constitute the goal, as it does wherever anger, revenge, or the ideal value of victory as such motivates a fight. (2) The second type of competition ... consists only in the fact that each competitor by himself aims at the goal, without using his strength on the adversary. . . . This type of competition equals all other kinds of conflict in intensity and passionate effort. It is pushed to its utmost concentration by the reciprocal consciousness of the participants that each of them so concentrates. And yet, from a superficial standpoint, it proceeds as if there existed no adversary but only the aim [1955, pp. 57-58].

The first of these two types may involve efforts to discredit, eliminate, shame, or "show up" the opponent, while the second simply involves efforts to "outdo" the opponent. Von Wiese and Becker (1932) also seem to have these types in mind:

There are two varieties of competition. The basis of the first is largely subjective; it is 
closely correlated with the wish for recognition and the concomitant tendency of the latter toward rivalry, and for present purposes it may be termed rivalry. The second has an appreciable subjective element, especially if striving is conscious, but its objective factors are more prominent than in the case of rivalry; the scarcity, real or supposed, of the objects or objectives striven for is perhaps the predominant component [pp. 250-51].

Ross (1930) carries the opponent-centered aspect of some forms of competition even further when he states that "the first impulse of a menaced organization or institution is to destroy the competitor" (p. 176), which can be done through price wars and other means of "unfair" or "cutthroat" competition, such as "verbal injury to the opponent's reputation" (Lawner, 1956). Bernard (1949) distinguishes some forms of competition which are as opponent-centered as the more intense forms of conflict:

Competition also varies along a continuum. .... At one end, corresponding to the lowest level of conflict, it is "cutthroat," often violent, ruthless. The effort, as in conflict, is to get rid of the competitor. . . But competition may be exploitative also. One may not be able to get rid of the competitor, but one may at least try to take unfair advantage of him [p. 53].

She also distinguishes a type called "Richardson competition" in which each competitor attempts to "outachieve" or "outdo" the opponent, exemplified by races of all kinds such as arms races, auctions, keeping up with the Joneses, rate-busting, pacesetting, the potlatch, and so on (1960, pp. 29-30). And Zadrozny (1959) seems to regard the opponent-centered aspect as basic to both conflict and competition, since he defines opposition as "a category of social processes including both competition and conflict, in which groups of people are essentially antagonistic to each other, and seek to destroy, subordinate, or thwart each other" (p. 234).

\section{LOCUS OF THE GOAL OBJECT}

It is thus apparent that the relative importance of object-centered vs. opponentcentered motivation is not a generally accepted criterion for distinguishing competition from other forms of struggle. More specific classifications of the aims of the parties have met with a similar lack of acceptance. For example, Simmel emphasizes the initial location of the goal object:

The pure form of the competitive struggle is above all not offensive and defensive, for the reason that the prize of the fight is not in the hands of either adversary. ... In many ... other types of conflict . . . the prize is originally in the hands of one of the parties, or . . . an initial hostility, rather than the attainment of a prize, motivates the fight. ... The aim for which competition occurs within a society is presumably always the favor of one or more third parties [Simmel, 1955, pp. 57-61].

This was also emphasized in Ross's statement that competition implies that the parties seek "the favor of certain individuals or bodies" with reference to the goal object (1930, p. 166). MacIver (1942), defining the competitive process as the "alternative offering of goods or services to a third party," recommended that various other forms of rivalry and struggle which are often loosely called "competition," but which do not involve contention for the favor of a third party, should be given other labels, such as "concurrence" and "bargaining" (pp. 316-19). Locus of the prize was the only basis used by Kerr (1954, p. 231) to distinguish between competition (in which "two or more parties seek to gain reward from a third party or parties") and conflict (in which "two or more parties seek to gain from each other").

But most writers either ignore this aspect of the goal object, or else use it to distinguish between types of competition or between types of (noncompetitive) conflict. 
For example, in Mack and Snyder's conception of competition (1957, p. 217), the prize or resource is usually (but not necessarily) "awarded" by a third party, implying that there are cases of competition that do not involve a third party. Bernard (1960) makes it a central criterion for distinguishing two main types of competition: "decisive competition" involves the selection of winners by a decision-maker whom the competitors try to influence; while "autonomic competition" involves the selection of winners by the process itself, so that no third party need be involved. Most definitions of (noncompetitive) conflict, on the other hand, do not imply that the goal object is always in the hands of the opponent. For example, Lasswell (1931) indicates that this is only one of several possible situations:

Conflict may involve the defense of what one already has or the acquisition of what one has not; and acquisition may mean the taking away of that which pertains to another or the appropriation of that which another would like to have [p. 195].

These alternatives are also implied in Mack and Snyder's assertion (1957, pp. 218-19) that conflict relations always involve attempts "to gain control of scarce resources and positions." Furthermore, whenever a conflict is over an object that is initially in the hands of neither opponent, it may or may not be in the hands of a third party. Thus, the initial locus of the goal object does not provide a generally accepted basis for distinguishing competition from (other forms of) conflict.

\section{SCARCITY OF THE GOAL OBJECT}

Some definitions of competition emphasize the scarcity of the goal object regardless of its initial location. This is often contrasted with a definition of conflict as based on inconsistency or incompatibility of aims.
For example, among several other criteria, Williams (1947) included the notion that in competition the goals are "scarce, distributive values" while in conflict the goals are "exclusive values" (distributive or nondistributive). According to Bernard (1949), the key source of competition is "scarcity," while the source of conflict is "incompatibility":

Theoretically the two basic questions to be answered by all communities-(1) if there is not enough of a thing, how can we decide who gets what there is? and (2) if there are many goals, values, or interests, which shall prevail? -are clear-cut and distinct. The first is the problem of scarcity, and it leads to competition; the second is the problem of incompatible wills, wishes, or interests, and it leads to conflict. . . . When two or more persons want the same thing we have competition, and when they want different but mutually incompatible things we have conflict [pp. 46-47].

Wright (1951) asserts that competition is based on striving for "something of which the supply is inadequate to satisfy all," while conflict is based on "inconsistencies in the sentiments, purposes, claims, or opinions of social entities." On similar grounds, Aubert (1963) distinguishes two main forms of conflict which he calls "competition" (conflict of interest) and "dissensus" (conflict of value or belief):

Two kinds of conflict are readily distinguishable in terms of their bases, the conflict of interest and the conflict of values or belief. ... . A conflict of interest between two actors stems from a situation of scarcity. Both $\mathrm{A}$ and $\mathrm{E}$ want "the same thing," but there is not enough of it available for each to have what he wants. ... Competing or contrasting interest does not in itself imply any disagreement between Ego and Alter concerning values. It may even be claimed that a conflict of interest presupposes a consensus, at least on the value of the good which is sought after by both parties. . . . In this sense, a conflict of interest is less fundamental than certain conflicts of values, which may amount to mutual denial of membership 
in the human race. ... A conflict of value is based upon a dissensus concerning the normative status of an object. In itself, there is nothing about a dissensus that should lead individuals to attack each other. Nevertheless there is no doubt that disagreements over values as well as over facts have often contributed to overt and aggressive conflict behavior, most blatantly in religious and ideological wars [pp. 27-29].

Other definitions of competition also emphasize scarcity (e.g., Doob, 1952; Friedsam, 1964), and a number of definitions of conflict emphasize incompatibility or mutual exclusiveness of values or aims (e.g., Lasswell, 1931; North et al., 1960; Berelson and Steiner, 1964; Galtung, 1965b; Loomis, 1967).

All of these distinctions parallel MacIver's distinction between conflicts based on "inharmonious like interests" and those based on "unlike attitudes":

There is conflict whenever like interests are inharmonious. The simplest case is that of two or more persons or groups who want the same individual thing. "What I want you want" means . . . conflict when the interest is exclusive. Anything that is scarce relative to the competing desires of people to have and to enjoy, whether it be a commodity, a loved one, an honor, a position of power, is a condition of conflict.... [In] the other great type ... the conflict situation ... takes the form "What I love you hate." This is primarily an expression of unlike attitudes. These may themselves arise out of discordant like interests, as in class warfare, or may be largely independent of such conditions, as in religious antagonism and other forms of cultural clash [1937, pp. 53-54].

But there is an important difference, since MacIver does not identify the first type with "competition." Although he might agree that all competition involves a scarce object, his discussion implies that some other forms of conflict are also based on scarcity, which means that "inharmonious like interests" vs. "unlike attitudes" is not used as a criterion for distinguishing competition from other forms of conflict. This is even clearer in DeKadt's (1965) use of a similar criterion to distinguish two types of conflict:

Conflicts derive from the existence of mutually exclusive or incompatible interests. Under certain circumstances in social life individuals and groups find that they simultaneously desire the same scarce objects or resources, or that they hold incompatible values orienting their activities. Thus there are two basic types of social conflict. The first relates to the distribution of scarce resources. We could call them scarcity or distributional conflicts. . . . The second type are conflicts over the different interests to which action might be orientedin a general sense value conflicts. In these cases control of behavior is sought by reference to general standards on which disagreement exists: groups hold values which differ from each other, and each tries to ensure that its own values are dominant in the situation [p. 457].

Like MacIver, DeKadt apparently does not mean to equate "scarcity conflict" with "competition," since his definition of conflict is taken from Bernard (1957a).

In addition to MacIver and DeKadt, many other writers assert that not only competition but also many or all cases of noncompetitive struggle are based on scarcity (e.g., Carver, 1915; Coser, 1956, 1964; Mack and Snyder, 1957; Stagner, 1967). Lundberg (1939) even suggests that conflict is characterized by a greater degree of scarcity than is competition. On the other hand, not all definitions of competition emphasize scarcity as a defining element. According to Von Wiese and Becker (1932), only one type of competition is based on scarcity. Other writers assert that both competition and (other forms of) conflict are based on incompatibility or mutual exclusiveness (e.g., Deutsch, 1956; Levinger, 1957; Dahrendorf, 1959; Boulding, 1962; Timasheff, 1965). Levinger's 
distinction between "competitive relationships" and "fight relationships" is especially interesting because it parallels the distinctions made by MacIver and DeKadt, but without relying on the notion of scarcity: in competition, the parties are attracted toward the same goals, but they are "contriently interdependent" (i.e., when A approaches his goal, he hinders B from entering the goal region or even pushes $\mathrm{B}$ away from his goal); while in fight relationships, the parties' goal regions lie in opposite directions and are incompatible (1957, pp. $337-38)$. In any event, it is clear that the "scarcity vs. incompatibility" dimension is not generally accepted as a basis for distinguishing competition from other forms of struggle.

\section{OTHER DISTINGUISHING FEATURES}

Still other criteria for the distinction have been suggested, but have received much less acceptance than those discussed above. For example, Park and Burgess associated competition with the "economic order" (1924, p. 574), but most other writers reviewed above ignore such boundaries. Tarde (1899) did restrict competition to the economic realm, but Carver (1915) and Hamilton (1931), both economists, included noneconomic competition in their discussions, and many others have discussed "economic conflicts" which are noncompetitive. A more recent example is the scheme presented by Beals and Siegel (1966) in which conflicts are classified according to their effects (perceived or actual) on the organizations or communities in which they occur: competition is "pseudoconflict," which is nondisruptive and seen as beneficial; while other forms of conflict are to some extent disruptive and seen as detrimental by group members (pp. 20-22). While several other classifications of conflict phenomena are based on the effects of the struggle (e.g., Simpson, 1937; Singer, 1949b; Lawner, 1956; Dicks, 1963), none of them distinguish competition on such grounds, and many writers discuss both disruptive forms of competition and nondisruptive forms of (noncompetitive) conflict. Additional criteria could be mentioned, but those reviewed here include the ones most frequently used to distinguish competition from (other forms of) conflict.

\section{The Need for a Broad}

\section{Definition of Conflict}

As noted earlier, proponents of narrow definitions of social conflict focus their arguments on the need to make certain conceptual distinctions which they feel are obscured by broader definitions. These arguments are epitomized in the following statement by Glass (1966, pp. 152-53):

No doubt, a definition of "conflict" can be found that would serve as an umbrella for a vast variety of processes and phenomena. But -quite apart from the fact that any such definition would prompt a good deal of arid controversy-it would have the disadvantage that it might become self-perpetuating; it would impart a spurious likeness to diverse manifestations, and also make it more difficult to see their actual interrelationships. ... Such a . . . definition can convey, or can be interpreted as conveying, far more kinship between the different species of "conflict" than actually exists. Even if there is some similarity in their processes, there is hardly any in their implications, their pervasive capacity, and in their effects.

But the preceding analysis indicates that the adoption of a narrow conception of conflict is no less controversial, and could not by itself prevent the glossing over of crucial differences between various species of struggle. There are many dimensions on which one may narrow the definition of conflict, corresponding to the various properties and sets of properties which may 
be used as defining characteristics. The question of excluding competition is itself complex, involving decisions about the relative importance of at least the following variables:

(a) regulated vs. unregulated

(b) indirect (parallel striving) vs. direct (mutual interference)

(c) unconscious vs. conscious

(d) impersonal vs. personal

(e) continuous vs. intermittent

(f) communication absent vs. communication present

(g) high communication vs. low communication

(h) peaceful vs. violent

(i) large admixture of cooperation vs. relatively pure antagonism

(j) object-centered vs. opponent-centered

(k) third party controls goal vs. opponent controls goal

(1) based on scarcity vs. based on incompatibility, inconsistency, etc.

(m) economic goals vs. noneconomic goals

(n) nondisruptive vs. disruptive

Choices among these variables are partly contingent on other decisions, such as the question of whether or not "presence of overt struggle" should be a defining characteristic of conflict. But these decisions are also partly independent of each other, with the result that a great variety of specific combinations of properties have been listed as criterial attributes. Further variables would emerge from analysis of the shifting conceptual boundaries between conflict and other terms such as "rivalry," "opposition," "antagonism," "tensions," etc. However, the above is sufficient, at this stage in the argument, to show that adoption of one of the many possible narrow definitions of social conflict would focus attention on only a small number of the many conceptual distinctions which various authors have felt to be theoretically important.

Given the disadvantages of both broad and narrow conceptions of conflict, one might seriously consider dropping the term altogether, as suggested (but not carried out) by Bernard (1957a, p. 111):

Scientific concepts . . . arise, serve their purpose, decline, and pass off the stage. If they overstay their usefulness, they may come to inhibit or impede, rather than stimulate or facilitate, creative thinking and research. The concept of "conflict" may fall into this category of outmoded concepts; it has no clear-cut referent, being emotion-fraught, value-laden, fuzzy, and equivocal. It confuses analysis. We might sharpen our thinking in the behavioral sciences if we discarded it entirely and replaced it with more precise, meaningful, and neutral concepts.

The feasibility of such an approach is indicated by the availability of a number of terms which are in certain contexts synonymous with conflict (in the broad sense). One example is "competition," but this would merely involve trading one highly ambiguous term for another. "Rivalry" has sometimes been used in a broad sense to cover all forms of antagonistic relations (e.g., Hamilton, 1931), and "opposition" has been used in this way by many writers (e.g., Wright, 1951; Zadrozny, 1959; Mack, 1965). Tarde (1899), in his theory of "diametrical social opposition" (social strife), manages to discuss the same phenomena without using the term "conflict" at all. Among the Social Darwinists and their critics, "struggle for existence" or simply "struggle" served the same purpose (Novicow, 1896, 1911); and Secher uses the latter in a recent translation of Max Weber's Basic Concepts in Sociology (1962, p. 85), where Henderson and Parsons had earlier used "conflict" in translating the same passage (Weber, 1947, p. 132). Sorokin (1928), objecting to the ambiguity of "struggle for existence," prefers "antagonistic struggle" or "antagonistic relations"; and in his later scheme for classifying "antagonistic systems of interaction" (1947), 
does not use either "competition" or "conflict" for designating special types.

In line with Bernard's suggestion, one might therefore replace the general theory of "social conflict" with a general theory of "social opposition," "social strife," or "social antagonisms." But there would still be a need to construct a conceptual scheme for describing and classifying the phenomena falling within the domain of the theory, and to assign labels to those concepts and phenomena. It is difficult to see how dropping the term "conflict" would be of much help in the process of conceptual clarification, since all of the synonyms are ambiguous to some degree, and since the basic problem lies in the definitional system itself. Furthermore, one would still be left with the question of how broadly or narrowly to construe the domain of the theory. And this is basically a question of theoretical scope which no amount of terminological legislation or conceptual clarification can settle.

In light of the above, the case for a broad conception of social conflict can be seen as a simple extension of the case for a generalist approach. The arguments for narrow conceptions of conflict are like the specialist arguments reviewed earlier, but instead of the nature of the parties they emphasize psychological and behavioral criteria for limiting the range of application. In both cases, the issue is the same: How broad a class of phenomena can conveniently and fruitfully be accounted for by means of a single theory? Those who prefer narrow conceptions are pointing to the existence of theoretically important differences between the phenomena they label "conflict" and other kinds of antagonistic relations. Those who prefer broad conceptions are pointing to the existence of theoretically significant similarities among var- ious forms of antagonism. But it is not necessary to choose between ignoring the similarities and ignoring the differences, since both can be dealt with by a properly constructed general theory. Furthermore, adoption of a broad conception of conflict to emphasize crucial similarities would in no way preclude the construction of a systematic classification scheme to emphasize crucial differences.

One argument for a generalist approach was that a general theory is necessary to the development of an adequate set of special theories, since the latter presupposes an adequate classification of conflict phenomena. The lack of agreement on sociocultural criteria, reflected in party-based classifications, thus justified further work toward a general theory of conflict. Similarly, the lack of agreement on psychological and behavioral criteria, reflected in the diverse distinctions between competition and conflict, indicates the extent of the taxonomic dilemma and the need to work toward an adequate classification of antagonistic relations in general.

Finally, the present analysis has only begun to elucidate the conceptual and terminological confusions which characterize the field as a whole. A premature exclusion of certain phenomena (e.g. competition) from consideration would impose excessive restrictions on the range of concepts and terms that could be brought into the analysis. This might unnecessarily prevent us from noticing certain key variables which will in the long run have to be taken into account.

Therefore, without insisting too strongly on retaining the term "conflict," I would argue that the aim of developing a general theory of social conflict can best be pursued if we adopt the broadest possible working definition of social conflict. By 
this I mean a definition which may be broader than any of those reviewed above, so as to include within the domain of the theory all phenomena which have been considered seriously as instances of social conflict, as well as many phenomena which are usually given other names. Such breadth is implied by defining social conflict as any social situation or process in which two or more social entities are linked by at least one form of antagonistic psychological relation or at least one form of antagonistic interaction. This emphasizes that while antagonism (which for the moment remains undefined) is the common element in all conflicts, there are a number of different kinds of psychological antagonisms (e.g., incompatible goals, mutually exclusive interests, emotional hostility, factual or value dissensus, traditional enmities, etc.) and a number of different kinds of antagonistic interaction (ranging from the most direct, violent, and unregulated struggle to the most subtle, indirect, and highly regulated forms of mutual interference), none of which is necessarily present in all instances of conflict. This is a disjunctive definition which subsumes any form of social antagonism, thus making the theory of conflict equivalent to a theory of antagonistic social relations in general, and strongly implying the need to develop a systematic classification of these phenomena as an essential supplement to the definition. The development of such a classification scheme will be pursued in subsequent chapters.

\section{REFERENCES}

ANGeil, Robert C. "The Sociology of Human Conflict." In E. McNeil (ed.), The Nature of Human Conflict. Englewood Cliffs, N. J.: Prentice-Hall, 1965.

Aron, Raymond. "Conflict and War from the Viewpoint of Historical Sociology." In International Sociological Association, The Nature of Conflict. Paris: UNESCO, 1957.
Aubert, Vilhelm. "Competition and Dissensus: Two Types of Conflict and of Conflict Resolution," Journal of Conflict Resolution, 7, 1 (March 1963), 26-42.

Beals, Alan R., and Bernard J. Siegel. Divisiveness and Social Conflict: An Anthropological Approach. Stanford: Stanford University Press, 1966.

Berelson, B., and G. Steiner. Human Behavior: An Inventory of Scientific Findings. New York: Harcourt, Brace, and World, 1964.

Bernard, Jessie. American Community Behavior: An Analysis of Problems Confronting American Communities Today. New York: Dryden Press, 1949.

- "Where is the Modern Sociology of Conflict?”, American Journal of Sociology, 56 (1950), 11-16.

-. "The Theory of Games of Strategy as a Modern Sociology of Conflict," American Journal of Sociology, 59 (1954), 411-24.

-. "Parties and Issues in Conflict," Journal of Conflict Resolution, 1, 2 (June 1957a), 111-21.

- "The Sociological Study of Conflict." In International Sociological Association, The Nature of Conflict. Paris: UNESCO, 1957b.

. "Autonomic and Decisive Forms of Competition," Sociological Quarterly, 1 (January 1960), 25-38.

- "Some Current Conceptualizations in the Field of Conflict," American Journal of Sociology, 70, 4 (January 1965), 442-54.

Biddle, B. J., ANd E. J. Thomas (eds.). Role Theory: Concepts and Research. New York: Wiley, 1966.

- J. Paschal Twyman, and Earl F. Rankin, Jr. "The Concept of Role Conflict." In Oklahoma State University Arts and Sciences Studies, Social Studies Series, No. 11 (no date).

Boulding, KenNeTh. "Organization and Conflict," Journal of Conflict Resolution, 1, 2 (June 1957), 122-34.

- Conflict and Defense: A General Theory. New York: Harper, 1962.

Carver, Thomas N. "The Basis of Social Conflict," American Journal of Sociology, 13 (1908), 628-37.

- "The Forms of Human Conflict." In T. N. Carver, Essays in Social Justice. Cam- 
bridge, Mass.: Harvard University Press, 1915.

Chase, Stuart. Roads to Agreement. New York: Harper, 1951.

Ciba Foundation. Conflict in Society (A. de Reuck and Julie Knight [eds.]). London: Churchill, 1966.

Coleman, James S. "Social Cleavage and Religious Conflict," Journal of Social Issues, 12, 3 (1956), 44-56.

- Community Conflict. Glencoe, Ill.: Free Press, 1957.

Cooley, Charles H. Social Process. New York: Scribner's, 1918.

- "Personal Competition." In C. H. Cooley, Sociological Theory and Social Research. New York: Henry Holt, 1930.

COSER, LEwIS A. The Functions of Social Conflict. Glencoe, Ill.: The Free Press, 1956.

- "Conflict." In J. Gould and W. L. Kolb (eds.), A Dictionary of the Social Sciences. New York: Free Press of Glencoe, 1964.

- Continuities in the Study of Social Conflict. New York: Free Press, 1967.

DAHRENDORF, RALF. "Toward a Theory of Social Conflict," Journal of Conflict Resolution, 2, 2 (June 1958), 170-83.

- Class and Class Conflict in Industrial Society. Stanford: Stanford University Press, 1959.

- Gesellschaft und Freiheit. Munich: R. Piper, 1961.

- _- Essays in the Theory of Society. Stanford: Stanford University Press, 1967.

Davies, James C. "Toward a Theory of Revolution," American Sociological Review, 27 (1962), 5-19.

Davis, K. Human Society. New York: Macmillan, 1949.

DeKadt, E. J. "Conflict and Power in Society," International Social Science Journal, 17, 3 (1965), 454-71.

Deutsch, Morton. "The Effects of Cooperation and Competition Upon Group Process." In D. Cartwright and A. Zander (eds.), Group Dynamics. Evanston, Ill.: Row, Peterson, 1953.

Dicks, H. V. "Conflict in the Family," New Society, 60, 2 (November 1963), 11-12.

Dodson, Dan W. "The Creative Role of Conflict in Intergroup Relations," Merrill-Palmer Quarterly, 4, 3 (July 1958), 189-95.
- "The Creative Role of Conflict Reexamined," Journal of Intergroup Relations, 1, 1 (Winter 1960), 5-12. [With comments by A. F. Miller, 13-19; and G. Schermer, 20-23.]

Doob, L. Social Psychology. New York: Henry Holt, 1952.

Dubin, Roвert. "Industrial Conflict and Social Welfare," Journal of Conflict Resolution, 1, 2 (June 1957), 179-99.

FrIEdLand, Wrixiam $H$. "The Institutionalization of Labor Protest in Tanganyika and Some Resultant Problems," Sociologus, 11 (1961), 132-46.

Fruedsam, H. "Competition." In J. Gould and W. Kolb (eds.), A Dictionary of the Social Sciences. New York: Free Press of Glencoe, 1964.

Galtung, Johan. "Pacifism from a Sociological Point of View," Journal of Conflict Res. olution, 3, 1 (March 1959), 67-84.

- "A Structural Theory of Aggression," Joumal of Peace Research, 1, 2 (1964), 95-119.

-. "On the Meaning of Nonviolence," Journal of Peace Research, 2, 3 (1965a), 228-57.

-. "Institutionalized Conflict Resolution: A Theoretical Paradigm," Journal of Peace Research, 2, 4 (1965b), 348-96.

Glass, Rutr. "Conflict in Cities." In Ciba Foundation (A. de Reuck and Julie Knight [eds.]), Conflict in Society. London: Churchill, 1966.

Gluckman, M. Rituals of Rebellion in Southeast Africa. Manchester: Manchester University Press, 1954.

- Custom and Conflict in Africa. Glencoe, Ill.: Free Press, 1955.

Goldman, Ralph M. "A Theory of Conflict Processes and Organizational Offices," Journal of Conflict Resolution, 10, 3 (September 1966), 328-43.

Gross, Feliks. World Politics and Tension Areas. New York: New York University Press, 1966.

HAGER, DoN H. "Introduction: Religious Conflict," Journal of Social Issues, 12, 3 (1956), 3-11.

-, C. Y. Glock, and I. Chein (eds.). "Religious Conflict in the U.S.," Journal of Social Issues, 12, 3 (1956). 
Hamlton, W. H. "Competition." In E. R. Seligman and A. Johnson (eds.), Encyclopedia of the Social Sciences, Vol IV. New York: Macmillan, 1931.

Hines, JosepH S. "The Functions of Racial Conflict," Social Forces, 45, 1 (September 1966), 1-10.

HoLsti, K. J. "Resolving International Conflicts: A Taxonomy of Behavior and Some Figures on Procedures," Journal of Conflict Resolution, 10, 3 (September 1966), 272-96.

Horowitz, Irving L. "Consensus, Conflict, and Cooperation: A Sociological Inventory," Social Forces, 41, 2 (December 1962), 17788.

IntERnational Sociological Association (in collaboration with J. Bernard, T. H. Pear, R. Aron, and R. C. Angell). The Nature of Conflict. Paris: UNESCO, 1957.

JANOwITZ, M. "Military Elites and the Study of War," Journal of Conflict Resolution, 1 (1957), 9-19.

Johnson, Chalmers. Revolutionary Change. Boston: Little, Brown, 1966.

KahN, Robert L., and Elise Boulding (eds.). Power and Conflict in Organizations. New York: Basic Books, 1964.

KerR, C. "Industrial Conflict and Its Mediation," American Journal of Sociology, 60 (1954), 230-45.

Koch, Howard E., Jr., Robert C. North, and Dina A. Zinnes. "Some Theoretical Notes on Geography and International Conflict," Journal of Conflict Resolution, 4, 1 (March 1960), 4-14.

KuHn, T. S. The Structure of Scientific Revolutions. Chicago: University of Chicago Press, 1962.

Lasswell, H. D. "Conflict: Social." In E. R. Seligman and A. Johnson (eds.), Encyclopedia of the Social Sciences, Vol. IV. New York: Macmillan, 1931.

Lawner, Rhoda L. "Social Conflict as a Subject of Investigation in American Research from 1919 to 1953." Unpublished doctoral dissertation, New York University, 1956.

LEVINE, RoBert A. "Anthropology and the Study of Conflict: Introduction," Journal of Conflict Resolution, 5, 1 (March 1961), 3-15.

LeVINGER, GeORGe. “Kurt Lewin's Approach to Conflict and Its Resolution: A Review with Some Extensions," Journal of Conflict Resolution, 1, 4 (December 1957), 329-39.

LEwin, KurT. Resolving Social Conflicts. New York: Harper, 1948.

Loomis, Charles P. "In Praise of Conflict and Its Resolution," American Sociological Review, 32, 6 (December 1967), 875-90.

LuNDBERG, G. A. Foundations of Sociology. New York: Macmillan, 1939.

MACIver, Robert M. Society: A Textbook of Sociology. New York: Farrar and Rinehart, 1937.

. Social Causation. New York: Ginn \& Company, 1942.

Mack, Raymond W. "The Components of Social Conflict," Social Problems, 22, 4 (Spring 1965), 388-97.

, and Richard C. Snyder. "The Analysis of Social Conflict-Toward an Overview and Synthesis," Journal of Conflict Resolution, 1, 2 (June 1957), 212-48.

MCNeIL, Exton (ed.). The Nature of Human Conflict. Englewood Cliffs, N. J.: PrenticeHall, 1965.

Marwell, Gerald. "Conflict Over Proposed Group Actions: A Typology of Cleavage," Journal of Conflict Resolution, 10, 4 (December 1966), 427-35.

Merton, Robert K. Social Theory and Social Structure. Glencoe: Free Press, 1957.

- On Theoretical Sociology. New York: Free Press, 1967.

MURPHY, RoBert F. "Intergroup Hostility and Social Cohesion," American Anthropologist, 59 (1957), 1018-35.

Nicholson, Michael. "Tariff Wars and a Model of Conflict," Journal of Peace Research, 4, I (1967), 26-38.

North, R. C., H. E. Koch, and Dina A. ZinNEs. "The Integrative Functions of Conflict," Journal of Conflict Resolution, 4 (1960), 355-74.

Novicow, J. Les Luttes Entre Sociétés Humaines et Leur Phases Successives. Paris: Alcan, 1896.

- (Translation by T. Seltzer). War and Its Alleged Benefits. New York: Henry Holt, 1911 (original French edition, 1894).

Ogburn, W. F., and M. F. Nrmkoff. Sociology. Boston: Houghton Mifflin, 1942.

$\mathrm{P}_{\mathrm{ARK}}, \mathrm{R} . \mathrm{E}$., and $\mathrm{E}$. W. Burgess. Introduction to the Science of Sociology. Chicago: University of Chicago Press, 1924. 
Patterson, John Stahl. Conflict in Nature and Life: A Study of Antagonism in the Constitution of Things. New York: D. Appleton and Company, 1883.

Price, Maumice T. "The Concept of "Culture Conflict': In What Sense Valid?," Social Forces, 9, 2 (December 1930), 164-67.

Rapoport, ANatol. Fights, Games and Debates. Ann Arbor: University of Michigan Press, 1960.

- "Game Theory and Human Conflict." In E. McNeil (ed.), The Nature of Human Conflict. Englewood Cliffs, N. J.: PrenticeHall, 1965.

Rex, Joun. Key Problems in Sociological Theory. London: Routledge and Kegan Paul, 1961.

Richardson, L. F. Arms and Insecurity. Pittsburgh: Boxwood, 1960a.

-. Statistics of Deadly Quarrels. Chicago: Quadrangle, $1960 \mathrm{~b}$.

Rosenau, James N. "Internal War as an International Event." In J. N. Rosenau (ed.), International Aspects of Civil Strife. Princeton: Princeton University Press, 1964.

Ross, E. A. Principles of Sociology (First Revision). New York: Century, 1930.

Schelling, Thomas C. "The Strategy of Conflict: Prospectus for a Reorientation of Game Theory," Journal of Conflict Resolution, 2, 3 (September 1958), 203-64.

- The Strategy of Conflict. Cambridge: Harvard University Press, 1960.

Sharp, GeNe. "The Meanings of Nonviolence: A Typology (Revised)," Journal of Conflict Resolution, 3, 1 (March 1959), 41-66.

ShEPARD, H. A. "Responses to Situations of Competition and Conflict." In R. Kahn and Elise Boulding (eds.), Power and Conflict in Organizations. New York: Basic Books, 1964.

Siegel, B. J., and A. R. Beals. "Pervasive Factionalism," American Anthropologist, 62 (1960), 394-417.

StMmer, Grorg. "The Sociology of Conflict," American Journal of Sociology, 9 (1903-04), 490-525, 672-89, 798-811.

- (translation by Kurt $\mathrm{H}$. Wolff and Reinhard Bendix). Conflict and the Web of Group Affiliations. Glencoe, Ill.: Free Press, 1955.

Smpson, George, Conflict and Community:
A Study in Social Theory. New York: T. S. Simpson, 1937.

SingER, J. E., L. Radloff, and D. Wark. "Renegades, Heretics, and Changes in Sentiment," Sociometry, 26 (1963), 178-89.

SINGER, KURT. The Idea of Conflict. Melbourne: Melbourne University Press, 1949a.

- "The Meaning of Conflict," Australasian Journal of Philosophy, 27, 3 (December $1949 \mathrm{~b}$ ), 145-70.

- "The Resolution of Conflict," Social Research, 16, 2 (1949c), 230-45.

Sorokin, Pittrim A. "Sociological Interpretation of the 'Struggle for Existence' and the Sociology of War." In P. A. Sorokin, Contemporary Sociological Theories. New York: Harper, 1928.

-. "Solidary, Antagonistic, and Mixed Systems of Interaction." In P. A. Sorokin, Society, Culture, and Personality. New York: Harper, 1947.

- Sociological Theories of Today. New York: Harper and Row, 1966.

Stagner, Ross (ed.). The Dimensions of Human Conflict. Detroit: Wayne State University Press, 1967.

Tanter, R., and M. Midlarsky. "A Theory of Revolution," Joumal of Conflict Resolution, 11, 3 (September 1967), 264-80.

TARDE, G. L'opposition Universelle. Paris: F. Alcan, 1897.

- (translation by H. C. Warren). Social Laws. New York: Macmillan, 1899.

TrmashefF, Nrcholas S. War and Revolution. New York: Sheed and Ward, 1965.

Thurlings, J. M. G. "The Dynamic Function of Conflict," Sociologia Neerlandica, 2, 2 (Summer 1965), 142-60.

Van Doorn, J. A. A. "Conflict in Formal Organizations." In Ciba Foundation (A. de Reuck and J. Knight [eds.]), Conflict in Society. London: Churchill, 1966.

VoN WIESE, L. Sociology. New York: 0. Piest, 1941.

- and H. BECKER. Systematic Sociology. New York: Wiley, 1932.

WeBER, M. (translation by A. M. Henderson and T. Parsons). The Theory of Social and Economic Organization. Glencoe, Ill.: Free Press, 1947.

- (translation by H. P. Secher). Basic Concepts in Sociology. New York: Philosophical Library, 1962. 
WILliams, RoBIN. The Reduction of Intergroup Tensions. New York: Social Science Research Council, 1947.

Wright, Q. "The Nature of Conflict," Western Political Quarterly, 4, 2 (June 1951), 193-209.

- "The Escalation of International Con- flicts," Journal of Conflict Resolution, 9, 4 (December 1965), 434-49.

Young, K. Sociology. New York: American Book Company, 1949.

Zadrozny, J. T. Dictionary of Social Science. Washington, D. C.: Public Affairs Press, 1959. 